\title{
Türkiye ile Avrupa Birliği Ülkelerinin Lojistik Performanslarının Entropi Ağırlıklı Edas Yöntemiyle Karşılaştırılması
}

\author{
Mehmet Orhan ${ }^{1 *}$ \\ ${ }^{1}$ Gaziantep Üniversitesi, Sosyal Bilimler Enstitüsü, İşletme ABD, Gaziantep, Türkiye, (ORCID: 0000-0003-1160-0258)
}

(İlk Geliş Tarihi 1 Aralık 2019 ve Kabul Tarihi 31 Aralık 2019)

(DOI: 10.31590 /ejosat.657693)

ATIF/REFERENCE: Orhan, M. (2019). Türkiye ile Avrupa Birliği Ülkelerinin Lojistik Performanslarının Entropi Ağırlıklı Edas Yöntemiyle Karşılaştırılması. Avrupa Bilim ve Teknoloji Dergisi, (17), 1222-1238.

\section{$\ddot{O} \mathbf{z}$}

Dünya Bankası, ülkelerin lojistik faaliyetlerinin kıyaslanabilmesi için lojistik performans indeksi (LPI) geliştirmiştir. Bu indekslere ait verileri iki yılda bir yayınlanmaktadır. Bu çalışmada, Dünya Bankası tarafından yayınlanan 2018 yılına ait lojistik performans indeksi verilerini kullanarak Türkiye ile Avrupa Birliği ülkelerinin lojistik performanslarının ENTROPİ ağırlıklı EDAS yöntemi kullanılarak kıyaslanması amaçlanmıştır. Bu kapsamda çalışmada ilk olarak ülkeleri karşılaştırırken kullanılacak kriterlerin önem dereceleri ENTROPİ yöntemi ile belirlenmiştir. Daha sonra belirlenen kriter ağırlıkları kullanılarak EDAS yöntemiyle lojistik performanslarına göre ülkelerin sıralamaları yapılmıştır. Ayrıca lojistik performans indeksine göre ülkelerin sıralamaları karşılaştırılmıştır.

Bu çalışmada ENTROPİ yöntemiyle yapılan analizler sonucunda kriterlerin önem derecelerine göre; gümrükler, altyapı, lojistik yetkinlik, yük izleme ve takip edilebilirlik, zamanlama ve uluslararası sevkiyatlar biçiminde sıralanmıştır. Dolayısıyla çalışmada ülkelerin lojistik performanslarının kıyaslanmasında en önemli kriterin gümrükler olduğu tespit edilmiştir. ENTROPİ yöntemiyle belirlenen kriter ağılıkları kullanılarak EDAS yöntemiyle gerçekleştirilen analizler sonucunda ülkelerin lojistik performans sıralaması sırasıyla Almanya, İsveç, Danimarka, Hollanda, Avusturya, Belçika, Birleşik Krallık, Finlandiya, Fransa, İspanya, İtalya, Norveç, Çekya, Lüksemburg, Portekiz, Polonya, İrlanda, Macaristan, Slovenya, Estonya, Yunanistan, Türkiye, Kıbrıs, Hırvatistan, Litvanya, Bulgaristan, Slovakya, Malta ve Letonya'dır. Örneklemdeki lojistik performans indeksi sırası ile EDAS yöntemiyle gerçekleştirilen analizler sonucunda elde edilen sıralamalar karşılaştırıldığında 5 ülke (Hollanda, Danimarka, Lüksemburg, Litvanya ve Türkiye) daha üst sıraya çıkmış, 6 ülke (Belçika, Avusturya, Portekiz, Kıbrıs, Bulgaristan ve Slovakya) daha aşağı sıraya düşmüş ve 19 ülke (Almanya, İsveç, Birleşik Krallık, Finlandiya, Fransa, İspanya, İtalya, Norveç, Çekya, Polonya, İrlanda, Macaristan, Slovenya, Estonya, Yunanistan, Hırvatistan, Malta ve Letonya) sırasını korumuştur. Almanya ve İsveç yine ilk iki sırada yer almıştır. Türkiye'nin sırası lojistik performans indeksine göre örneklemde 23. sırada yer alırken analiz sonucunda 22 sıraya yükselmiştir.

\section{Comparison of the Logistics Performance between Turkey and European Union Member Countries with Entropy Weighted Edas Method}

\author{
Abstract
}

* Sorumlu Yazar: Gaziantep Üniversitesi, Sosyal Bilimler Enstitüsü, İşletme ABD, Gaziantep, Türkiye, ORCID: 0000-0003-1160-0258, mehmetorhan01@gmail.com 
In order to compare the countries' logistic operations, the World Bank developed the logistic performance index (LPI). Data for this index are published every two years. This study aims to compare Turkey's logistic performance with the European Union states by using the LPI of the year 2018 with ENTROPY weighted EDAS method. In this respect, firstly, the importance degree (weights)of the criteria to be used when comparing countries was determined with ENTROPY method. Afterwards, the ranking of the countries according to their logistic performance was made with EDAS method by using criteria weights as determined Furthermore, the rankings of the countries were compared with the logistics performance index.

In this study, as a result of the analysis made by ENTROPI method, the ranking of the criteria according to the importance degree is customs, infrastructure, logistics competence, freight tracking and traceability, timing and international shipments. Therefore, the most important criteria for comparing the logistic performance of the countries was found to be customs. As a result of the analyzes performed by EDAS method using criteria weights determined by ENTROPY method, the logistics performance rankings of the countries respectively are Germany, Sweden, Denmark, Netherlands, Austria, Belgium, United Kingdom, Finland, France, Spain, Italy, Norway, Czechia, Luxembourg, Portugal, Poland, Ireland, Hungary, Slovenia, Estonia, Greece, Turkey, Cyprus, Croatia, Lithuania, Bulgaria, Slovakia, Malta and Latvia. When the sequence obtained from the results of the analysis carried out with EDAS method compared logistics performance index rank in the sample, five countries (Netherlands, Denmark, Luxembourg, Lithuania and Turkey) increased their rank, six countries (Belgium, Austria, Portugal, Cyprus, Bulgaria and Slovakia) lower their rank and 19 countries (Germany, Sweden, United Kingdom, Finland, France, Spain, Italy, Norway, Czechia, Poland, Ireland, Hungary, Slovenia, Estonia, Greece, Croatia, Malta and Latvia) maintained their order. While Turkey's rank was 23 According to the logistics performance index in the sample, as a result of the analysis has increased to $22 \mathrm{nd}$ place.

Keywords: Logistics Performance, Logistics Performance Index, ENTROPİ, EDAS.

\section{Giriş}

Lojistik ilk olarak askeri ihtiyaçların karşılanmasına yönelik olarak ortaya çıkmış olmasına karşın bilgi ve iletişim teknolojilerinin etkisiyle değişen ve dönüşen günümüz koşullarında hayatın her aşamasında yer almaktadır. Lojistik, özellikle de işletmeler için vazgeçilemez hayati bir konuma yükselmiştir (Şirin ve Emanet, 2017:302; Özbek ve Demirkol, 2018; Aytekin, 2018). Lojistik genel olarak, ürün (nihai ürün, yarı mamül ve hammadde), bilgi ve paranın çıkış noktası ve nihai tüketim noktası arasındaki çift yönlü hareketleri ve bu hareket sürecleri esnasında oluşan tüm süreçlerin verimli ve etkili bir biçimde planlanması, uygulanması, kontrol edilmesi ve denetlenmesi şeklinde tanımlanmaktadır (Aytekin, 2018; Şirin ve Emanet, 2017: 302)

Türkiye'nin 2023 hedeflerine erişebilmesi amacıyla oluşturulan stratejilerin en önemlilerinden birisi, uluslararası arenada rekabet üstünlüğü oluşturarak dış ticarette önemli oyunculardan birisi olabilmektir. Dış ticarette sürdürülebilir başarının elde edilmesi, katma değerli ve çeşitlendirilmiş üretimin lojistik faaliyetlerle bütünleştirilmesiyle sağlanabilecektir. Lojistik sektörü, Türkiyede son 20 yıldır karayolu taşımacılığının yanında deniz, demir ve hava yollarının kullanılarak kombine taşımacılık sistemlerinin etkinleştirilmesi ve bilgi teknolojisi alt yapısının iyileştirilmesiyle gelişme göstermektedir. (Sezen vd., 2016:186). Türkiye'de lojistik sektörünün Gayri Safi Yurtiçi Hasıla (GSYH) içerisindeki payı yıllara göre \%10 ile \%20 arasında değişlik göstermektedir. (Yapraklı ve Ünalan, 2017:591).

Dünya çapında ticaret ve taşımacılık alanlarındaki serbestleşme eğilimlerinin hızla artması, lojistik sektörünü stratejik bir sektör haline gelmesini sağlamış ve lojistik sektörü küresel anlamada önemli büyüme rakamlarına ulaşmıştır (Yapraklı ve Ünalan, 2017:589; Sezen vd., 2016). Lojistik kavramının tüm dünyada hem işletme maliyetlerindeki hem de ülke ekonomilerindeki etkilerinin anlaşılmasıyla beraber ülkelerin lojistik performansı önemli göstergelerden biri haline gelmiştir. Bu noktadan hareketle, Dünya Bankası, lojistik performans üzerinde etkili olan 6 kriteri (gümrük, altyapı, uluslararası sevkiyatlar, lojistik kalite ve yetkinlik, takip ve izleme, zamanlama) kullanalarak ülkelerin lojistik performanslarını 2007 y1lından itibaren değerlendirmeye başlamış ve 2007, 2010, 2012, 2014, 2016 ve 2018 yıllarında da Lojistik Performans Endeksi (LPI) ismiyle iki yılda bir yayınlamıştır (Şirin ve Emanet 2017:302; Yaprakl1 ve Ünalan, 2017:589).

Bu çalışmada Türkiye ile Avrupa Birliği ülkelerinin lojistik performanslarının kıyaslamaları yapılmıştır. Ülkelerin lojistik performansların kıyaslamasında; Dünya Bankası Lojistik Performans Endeksi (LPI)'nin altı kriteri (gümrük, altyapı, uluslararası sevkiyatlar, lojistik kalite ve yetkinlik, takip ve izleme, zamanlama) kullanılmıştır. Bu kapsamda çalışmada Dünya Bankası 2018 yılında yayınlamış olduğu bu kriterlere ait veriler kullanılmıştır (http://databank.worldbank.org). Yapılan analizler sonucunda elde edilen bulgular çerçevesinde Türkiye'nin lojistik performansının geliştirilmesine yönelik önerilerde sunulmuştur.

\section{Literatür Taraması}

Literatürde hem lojistik sektörü ile ilgili hem de diğer sektörlerle ilgili çalışmalarda çok kriterli karar verme (ÇKKV) yöntemleri sıklıkla kullanılmaktadır. Bu teknikler aşağı yukarı 30 yıldan beri literatürde aktif şekilde kullanılmaktadır (Rençber, 2019:69-70). Literatürde sıklıkla kullanılan ÇKKV yöntemleri; EDAS (Evaluation based on Distance from Average Solution), TOPSIS (Technique for Order Preference by Similarity to Ideal Solution),VIKOR (Vise Kriterijumska Optimizacija Kompromisno Resenje), Değer Aralığı (Range of Value, ROV), Basit Toplamsal Ağırlıklandırma (Simple Additive Weighting, SAW), PROMETHEE (Preference Ranking Organization Method for Enrichment Evaluations), MULTI-MOORA (Multi-Objective Optimization on the basis of Ratio Analysis), Analitik Hiyerarşi Süreci (Analytic Hierarchy Process, AHP), Analitik Ağ Süreci (Analytic Hierarchy Network, ANP), Veri Zarflama 
Analizi (Data Envelopment Analysis, DEA), CRITIC (Criteria Importance Through Intercriteria Correlation), CODAS (Combinative Distance-based Assessment), Gri İlişkisel Analiz (Grey Relational Analysis, GRA), Kademeli Ağırlık Değerlendirme Oran Analizi (Step-Wise Weight Assessment Ratio Analysis, SWARA), VIKOR (Vise Kriterijumska Optimizacija Kompromisno Resenje), COPRAS (Complex Proportional Assessment) ve ELECTRE (Elimination and Choice Expressing Reality) yöntemleridir. Bu kapsamda Tablo 1 'de literatürde yapılan bazı çalışmalara ilişkin bilgiler sunulmuştur

Tablo 1. Literatür Taraması

\begin{tabular}{|c|c|c|c|c|}
\hline Yazar(lar) & Amaç & Yöntem & Kriter(ler) & Bulgu(lar) \\
\hline $\begin{array}{l}\text { Gök Kısa ve } \\
\text { Ayçin (2019) }\end{array}$ & $\begin{array}{l}\text { OECD ülkelerinin lojistik } \\
\text { performanslarının 2012- } \\
2018 \text { yıllarına göre } \\
\text { değerlendirilmesi }\end{array}$ & SWARA ve EDAS & $\begin{array}{l}\text { Gümrük Yönetimi } \\
\text { Altyapı } \\
\text { Uluslararası Sevkiyat } \\
\text { Lojistik Hizmet Kalitesi } \\
\text { Takip ve İzleme } \\
\text { Zamanlama }\end{array}$ & $\begin{array}{l}\text { En önemli kriterler lojistik hizmet kalitesi, altyapı ve } \\
\text { uluslararası sevkiyat olarak belirlenmiştir. Lojistik } \\
\text { performansı en yüksek olan ülkelerin ise sırasıyla } \\
\text { Almanya, Hollanda ve İsveç olduğu sonucuna } \\
\text { ulaşılmıştır. }\end{array}$ \\
\hline $\begin{array}{l}\text { Oğuz vd. } \\
\text { (2019) }\end{array}$ & $\begin{array}{l}\text { Yedi Asya ülkesinin } \\
\text { (Güney Kore, Hong } \\
\text { Kong, Singapur, } \\
\text { Endonezya, Malezya, } \\
\text { Tayvan ve Tayland) } \\
2018 \text { yılı lojistik } \\
\text { performans } \\
\text { değerlendirilmesi }\end{array}$ & TOPSIS & $\begin{array}{l}\text { Altyapı } \\
\text { Uluslararası Taşımacılık } \\
\text { Lojistik Hizmet Kalitesi } \\
\text { Takip Edilebilirlik } \\
\text { Zamanında Teslim }\end{array}$ & $\begin{array}{l}\text { Siralama sonucunda lojistik performansı en yüksek olan } \\
\text { ülkenin Singapur, en düşük olan ülkenin ise Endonezya } \\
\text { olduğu tespit edilmiştir. }\end{array}$ \\
\hline $\begin{array}{c}\text { Ulutaş ve } \\
\text { Karaköy } \\
(2019)\end{array}$ & $\begin{array}{l}\text { TAHA Kargo Dış } \\
\text { Ticaret A.Ş.'nin 2011- } \\
2017 \text { yıllarındaki } \\
\text { performans } \\
\text { değerlendirilmesi }\end{array}$ & $\begin{array}{l}\text { CRITIC ve } \\
\text { ROV (Değer } \\
\text { Aralığı) }\end{array}$ & $\begin{array}{l}\text { Net Satış } \\
\text { Net Satış Değişimi } \\
\text { Faiz, Vergi Öncesi Kâr } \\
\text { Faiz, Vergi Öncesi Kâr Değişimi } \\
\text { Aktif Toplam } \\
\text { Özkaynak } \\
\text { Çalışan Sayısı } \\
\text { İhracat }\end{array}$ & $\begin{array}{l}\text { Şirketin } 2017 \text { yılındaki performansı diğer yıllara göre } \\
\text { yüksektir }\end{array}$ \\
\hline $\begin{array}{l}\text { Özdemir ve } \\
\text { Güneroğlu } \\
\text { (2018) }\end{array}$ & $\begin{array}{l}\text { Kuru yük gemisi } \\
\text { şirketleri için kargo tipi } \\
\text { seçim problemi analiz } \\
\text { edilmesi }\end{array}$ & $\begin{array}{l}\text { Bulanık AHP ve } \\
\text { Bulanık } \\
\text { TOPSIS }\end{array}$ & $\begin{array}{l}\text { Net navlun karı } \\
\text { Kargo taşıma koşulları } \\
\text { Yolculuk başına toplam yakıt tüketimi } \\
\text { Korsanlık ve kaçak riski } \\
\text { Bir sonraki sefer için pozisyon } \\
\text { Kargo elleçleme maliyeti }\end{array}$ & $\begin{array}{l}\text { Kriterlerin önem sıralaması net navlun karı }(\% 9,85) \text {, } \\
\text { kargo taşıma koşulları }(\% \text { 6,35), yolculuk başına toplam } \\
\text { yakıt tüketimi }(\% 5,96) \text {, korsanlık ve kaçak riski }(5,08) \text {. } \\
\%) \text {, bir sonraki sefer için pozisyon }(\% 4,87) \text { ve kargo } \\
\text { elleçleme maliyeti }(\% 4,74) \text { biçimindedir. }\end{array}$ \\
\hline $\begin{array}{l}\text { Rençber ve } \\
\text { Avc1 } \\
(2018)\end{array}$ & $\begin{array}{l}\text { BIST'te işlem gören } \\
\text { bankaların sermaye } \\
\text { yeterlilikleri bakımından } \\
\text { kıyaslanması }\end{array}$ & WASPAS & Bankaların sermaye yeterlilik oranları & $\begin{array}{l}\text { Sermaye yeterliliği bakımından Albaraka, Kalkınma ve } \\
\text { TSKB bankaları en iyi iken QNB Finansbank ve } \\
\text { Denizbank'ın ise genelde düşük düzeyde oldukları } \\
\text { tespit edilmiştir. }\end{array}$ \\
\hline Ecer (2018) & $\begin{array}{l}4 \text { üçüncü parti lojistik } \\
\text { firmasının } \\
\text { performanslarının } \\
\text { değerlendirilmesi }\end{array}$ & $\begin{array}{c}\text { Bulanık AHP ve } \\
\text { Bulanık EDAS }\end{array}$ & $\begin{array}{l}\text { Maliyet } \\
\text { İlişki } \\
\text { Hizmetler } \\
\text { Kalite } \\
\text { Bilgi Sistemi } \\
\text { Esneklik } \\
\text { Teslimat } \\
\text { Profesyonellik } \\
\text { Finansal Pozisyon } \\
\text { Konum } \\
\text { İtibar }\end{array}$ & $\begin{array}{l}\text { B, D ve A ilk } 3 \text { üçüncü parti lojistik firması ve } \mathrm{D} \text { ise en } \\
\text { kötü üçüncü parti lojistik firmasıdır. }\end{array}$ \\
\hline $\begin{array}{l}\text { Özbek ve } \\
\text { Demirkol } \\
(2018)\end{array}$ & $\begin{array}{l}500 \text { listesinde yer alan } 8 \\
\text { lojistik firmasının } 2016 \\
\text { y1lındaki ekonomik } \\
\text { performans } \\
\text { değerlendirilmesi }\end{array}$ & SWARA GİA & $\begin{array}{l}\text { Net Satış Net Satış Değişimi Faiz, } \\
\text { Vergi Öncesi Kâr (FVÖK) } \\
\text { FVÖK Değişim } \\
\text { Aktif Toplam } \\
\text { Öz kaynak } \\
\text { İhracat } \\
\text { Çalışan Sayısı }\end{array}$ & $\begin{array}{l}\text { Performansı en yüksek firmanın Netlog olduğu } \\
\text { görülmüştür }\end{array}$ \\
\hline $\begin{array}{c}\text { Özbek } \\
2018\end{array}$ & $\begin{array}{l}2017 \text { y1lı Fortune } 500 \\
\text { Türkiye listesinde yer } \\
\text { alan } 8 \text { lojistik hizmeti } \\
\text { sunan firmanın } \\
\text { performans } \\
\text { değerlendirilmesi }\end{array}$ & $\begin{array}{c}\text { SWARA, } \\
\text { COPRAS,Gri } \\
\text { İlişkisel Analizi } \\
\text { ve TOPSIS }\end{array}$ & $\begin{array}{l}\text { Net Satış Net Satı̂s Değişimi Faiz, } \\
\text { Vergi Öncesi Kâr (FVÖK) } \\
\text { FVÖK Değişim } \\
\text { Aktif Toplam } \\
\text { Öz kaynak } \\
\text { İhracat } \\
\text { Çalışan Sayısı }\end{array}$ & $\begin{array}{l}\text { Lojistik hizmeti sunan firmaların performansları } \\
\text { değerlendirilmesinde en önemli kriterin Net Satış ve her } \\
\text { üç yönteme göre performansı en yüksek firmanın ise } \\
\text { "Netlog" olduğu ortaya konmuştur. }\end{array}$ \\
\hline
\end{tabular}




\begin{tabular}{|c|c|c|c|c|}
\hline $\begin{array}{l}\text { Özbek ve } \\
\text { Engür } \\
\text { (2018). }\end{array}$ & $\begin{array}{l}\text { Lojistik sektöründe } \\
\text { ulusal ve uluslararası } \\
\text { faaliyette bulunan } 7 \text { adet } \\
\text { firmanın web sitelerinin } \\
\text { değerlendirilmesi }\end{array}$ & EDAS & $\begin{array}{l}\text { Güncellik } \\
\text { Bilgi zenginliği } \\
\text { Müşteri ilişkileri } \\
\text { Yabancı dil seçenekleri } \\
\text { Online sipariş kabul } \\
\text { Ürün kataloğu } \\
\text { Görsel çekicilik (tasarım) } \\
\text { Kullanım kolaylığı (işlevsellik) } \\
\text { Özel misyon ya da web sitesi amaçları } \\
\text { İçerik, serbest kaynaklar vs.nin } \\
\text { yararları ve kalitesi } \\
\text { Algısal faktörler }\end{array}$ & $\begin{array}{l}\text { Web sitesi en iyi olan firmanın Omsan Lojistik olduğu } \\
\text { belirlenmiştir. }\end{array}$ \\
\hline $\begin{array}{l}\text { Ayrim vd. } \\
(2018)\end{array}$ & $\begin{array}{l}\text { Dört büyük kargo } \\
\text { taşımacılık şirketinin } \\
\text { performanslarının } \\
\text { değerlendirilmesi }\end{array}$ & $\begin{array}{l}\text { Stokastik } \\
\text { COPRAS }\end{array}$ & $\begin{array}{l}\text { Zamanında teslimat } \\
\text { Maliyet } \\
\text { Destek hizmeti } \\
\text { Teslimat güvenliği } \\
\text { Teslimat süresi }\end{array}$ & $\begin{array}{l}\text { Elde edilen bulgulara göre teslim süresi en önemli kriter } \\
\text { olarak belirlenmiş ve } \\
\mathrm{A}_{3} \text { firması en yüksek performansa sahiptir }\end{array}$ \\
\hline $\begin{array}{l}\text { Asoğlu ve } \\
\text { Eren (2018) }\end{array}$ & Kargo şirketi seçimi & $\begin{array}{l}\text { AHP, TOPSIS, } \\
\text { PROMETHEE }\end{array}$ & $\begin{array}{l}\text { Kargonun söz verilen sürede yerine } \\
\text { ulaştırılması } \\
\text { Personelin saygıllı ve istekli olması } \\
\text { Firma-müşteri arasında etkili bir } \\
\text { iletişimim imkânının olması } \\
\text { Kargoda oluşabilecek zararlar için } \\
\text { güvence verilmesi } \\
\text { Personelin müş̧teri problemini hızlı } \\
\text { çözebilmesi fiyatlandırmanın uygun } \\
\text { olması } \\
\text { Kargo kabulü ve tesliminin hızlı } \\
\text { yapılması }\end{array}$ & $\begin{array}{l}\text { Kargo şirketlerinin karşılaştırılması yapıldı̆̆ında } \\
\text { TOPSIS ve PROMETHEE yöntemlerinin sıralamasında } \\
\text { kargo şirketleri farklı sıralamaya sahiplerdir. }\end{array}$ \\
\hline $\begin{array}{l}\text { Tüysüz ve } \\
\text { Şimşek } \\
(2017)\end{array}$ & $\begin{array}{l}\text { Türkiye'deki bir kargo } \\
\text { firmasının şubelerinin } \\
\text { performansını etkileyen } \\
\text { faktörleri analiz } \\
\text { etmişlerdir ve bunların } \\
\text { önem derecelerinin } \\
\text { değerlendirilmesi. }\end{array}$ & Sezgisel AHP & $\begin{array}{l}\text { Operasyonel faktörler } \\
\text { İnsan kaynakları ile ilgili faktörler } \\
\text { Finansal faktörler } \\
\text { Müşteri ilişkileri ile ilgili faktörler } \\
\text { Satış ve pazarlama ile ilgili faktörler } \\
\text { Güvenlik ve güvenlikle ilgili } \\
\text { Diğer birimler ile ilgili faktörler }\end{array}$ & $\begin{array}{l}\text { Sonuçlara göre, güvenlik ve güvenlikle ilgili faktörler } \\
\text { en yüksek önem seviyesine sahiptir } \\
\text { Ardından satış ve pazarlama ile ilgili faktörler, müşteri } \\
\text { ilişkileri ile ilgili faktörler gelmektedir }\end{array}$ \\
\hline $\begin{array}{l}\text { Ergün ve } \\
\text { Aşıkoğlu } \\
(2016)\end{array}$ & $\begin{array}{l}\text { Lojistik köy olmaya en } \\
\text { elverişli merkez veya } \\
\text { merkezlerin belirlenmesi }\end{array}$ & TOPSIS & $\begin{array}{l}\text { Yerin Uygunluğu } \\
\text { Ulaşım Bağlantısı } \\
\text { Arazi Özellikleri } \\
\text { Yer ve Bağlantılı İş Aktiviteleri }\end{array}$ & $\begin{array}{l}\text { Lojistik köy iç en ideal ilk } 3 \text { aday sırasıyla Mersin- } \\
\text { Merkez, Konya-Merkez ve Bilecik-Bozüyük olarak } \\
\text { belirlenmiştir }\end{array}$ \\
\hline $\begin{array}{l}\text { Aguezzoul } \\
\text { ve Pires } \\
(2016)\end{array}$ & $\begin{array}{l}13 \text { üçüncü parti lojistik } \\
\text { firmasının performans } \\
\text { değerlendirilmesi }\end{array}$ & ELECTRE I & $\begin{array}{l}\text { Maliyet } \\
\text { İlişki } \\
\text { Hizmetler } \\
\text { Kalite } \\
\text { Bilgi ve ekipman sistemi } \\
\text { Esneklik } \\
\text { Teslimat } \\
\text { Profesyonellik } \\
\text { Finansal pozisyon } \\
\text { Konum } \\
\text { İtibar }\end{array}$ & $\begin{array}{l}\text { Dört farklı senaryoda en iyi üçüncü parti lojistik firması } \\
\text { belirlenmiştir. }\end{array}$ \\
\hline $\begin{array}{l}\text { Akbulut ve } \\
\text { Rençber } \\
\text { (2015) }\end{array}$ & $\begin{array}{l}\text { BIST’te işlem gören } \\
\text { İmalat sektöründeki } 32 \\
\text { işletmenin 2010-2012 } \\
\text { döneminde finansal } \\
\text { performanslarının } \\
\text { değerlendirilmesi }\end{array}$ & TOPSIS & $\begin{array}{l}\text { Likidite oranları, } \\
\text { Faaliyet oranları, } \\
\text { Karlılık oranları } \\
\text { Pazar değerinin defter değerine oranı }\end{array}$ & $\begin{array}{l}\text { İsletmelerin borsa performanslarıyla finansal } \\
\text { performansları arasında istatistik olarak anlamlı ilişki } \\
\text { olmadığı tespit edilmiştir }\end{array}$ \\
\hline $\begin{array}{l}\text { Mirzaei vd. } \\
\quad(2015)\end{array}$ & $\begin{array}{l}\text { İran'daki Ghaen şehri } \\
\text { kargo terminali için en } \\
\text { uygun yeri bulunması }\end{array}$ & Bulanık AHP & $\begin{array}{l}\text { Bölgesel konum } \\
\text { Arazi topografyası } \\
\text { Maliyet } \\
\text { Baskın rüzgar yönü } \\
\text { Çevresel tahribat } \\
\text { Gelecekte genişleme imkanı } \\
\text { Kargo merkezine uzaklık }\end{array}$ & $\begin{array}{l}\text { Sonuçlar, önerilen yöntemin, kargo terminalleri için en } \\
\text { uygun yerin seçilmesinde güvenilir bir yöntem } \\
\text { olduğunu göstermektedir. }\end{array}$ \\
\hline $\begin{array}{l}\text { Akman ve } \\
\text { Baynal } \\
(2014)\end{array}$ & $\begin{array}{l}\text { Lojistik hizmeti sağlayan } \\
\text { firma seçimi }\end{array}$ & $\begin{array}{l}\text { Bulanık AHP ve } \\
\text { Bulanık } \\
\text { TOPSIS }\end{array}$ & $\begin{array}{l}\text { Zamanında teslimat } \\
\text { Ürün erişilebilirliği } \\
\text { Güvenilirlik }\end{array}$ & $\begin{array}{l}\text { Lojistik hizmeti sağlayan firma seçiminde LSP7 firmas1 } \\
\text { en uygun firma olmuştur. }\end{array}$ \\
\hline
\end{tabular}




\begin{tabular}{|c|c|c|c|c|}
\hline & & & $\begin{array}{l}\text { Firma geçmişi } \\
\text { Firma itibarı } \\
\text { Bilgi paylaşımı } \\
\text { Esneklik }\end{array}$ & \\
\hline $\begin{array}{l}\text { Görener } \\
(2014)\end{array}$ & $\begin{array}{l}\text { Depolama faaliyetleri } \\
\text { için lojistik servis } \\
\text { sağlayıcı seçiminde } \\
\text { önemli değerlendirme } \\
\text { kriterlerinin belirlenmesi }\end{array}$ & ANP & $\begin{array}{l}\text { Firma Özellikleri, Maliyet, } \\
\text { Firmaya Ait Depoların Özellikleri, } \\
\text { Esneklik, Kalite, } \\
\text { Ambalajlama, Faaliyetleri, } \\
\text { Teknoloji, } \\
\text { İletişim Olanakları, } \\
\text { Risk Yönetimi, } \\
\text { Diğer Kriterler ve bu ana kritelerin alt } \\
\text { kriterleri }\end{array}$ & $\begin{array}{l}\text { Yapılan analiz sonucunda, "operasyonel yeterlilik" } \\
\text { kriterinin en önemli kriter olduğu saptanmıştır. }\end{array}$ \\
\hline $\begin{array}{l}\text { Bağci ve } \\
\text { Rençber } \\
(2014)\end{array}$ & $\begin{array}{l}\text { Kamu bankaları ile özel } \\
\text { bankalarının 2006-2012 } \\
\text { döneminde kârlılık } \\
\text { performansları } \\
\text { karşılaştırması }\end{array}$ & PROMETHEE & $\begin{array}{l}\text { Net kâr / toplam aktif } \\
\text { Net kâr / özkaynak toplamı } \\
\text { Vergi öncesi kâr / toplam aktif’ }\end{array}$ & $\begin{array}{l}\text { Kamu bankaları arasınada en kârlı banka Halk Bankası, } \\
\text { özel bankalar arasında ise Denizbank'tır. }\end{array}$ \\
\hline $\begin{array}{l}\text { Uzun } \\
(2013)\end{array}$ & $\begin{array}{l}\text { Kargo taşımacılık } \\
\text { sektöründeki hizmet } \\
\text { kalitesini etkileyen } \\
\text { etkenlerin ağırlıklarını } \\
\text { bulup, üç kargo } \\
\text { taşımacılık firmasının } \\
\text { performanslarının } \\
\text { değerlendirilmesi }\end{array}$ & $\begin{array}{l}\text { AHP ve } \\
\text { TOPSIS }\end{array}$ & $\begin{array}{l}\text { Firmaya Güvenirlik } \\
\text { Müşteriye Duyarlılık Hizmete } \\
\text { Ulaşılabilirlik }\end{array}$ & $\begin{array}{l}\text { A Kargo firmasının daha yüksek kalite düzeyine sahip } \\
\text { olduğu belirlenmiş; Ancak kurumsal müşteriler } \\
\text { açısından her iki yönteme göre de kargo firmaları } \\
\text { arasında kalite farkının az olduğu hesaplanmıştır. }\end{array}$ \\
\hline $\begin{array}{l}\text { Çakır ve } \\
\text { Perçin } \\
(2013)\end{array}$ & $\begin{array}{l}2011 \text { yılında Fortune } 500 \\
\text { listesinde yer alan } 10 \\
\text { lojistik firmasının } \\
\text { performansının } \\
\text { değerlendirilmesi }\end{array}$ & $\begin{array}{c}\text { TOPSIS, } \\
\text { VIKOR, } \\
\text { CRITIC, SAW } \\
\text { ve Borda Sayım }\end{array}$ & $\begin{array}{l}\text { Özkaynaklar } \\
\text { Aktifler } \\
\text { Kaldıraç Oranı Çalışan Sayısı } \\
\text { Net Satışlar } \\
\text { Esas Faaliyet Kâr Marjı }\end{array}$ & $\begin{array}{l}\text { Uygulama sonucunda çalışmada kullanılan bütünleşik } \\
\text { modelin performans ölçümü amacıyla kullanılabilecek } \\
\text { uygun bir yöntem olduğu ve uygulayıcılara tatminkâr } \\
\text { sonuçlar verdiği ortaya çıkmıştır. } \\
\text { Borusan Lojistik firması en yüksek performansı } \\
\text { gösteren firma olmuştur. }\end{array}$ \\
\hline $\begin{array}{c}\text { Özbek ve } \\
\text { Eren }(2012)\end{array}$ & $\begin{array}{l}\text { 3PL firmalarının seçimi } \\
\text { yapılması }\end{array}$ & AHP & $\begin{array}{l}\text { Kalite } \\
\text { Uzun süreli ilişki } \\
\text { Firma imajı } \\
\text { Operasyonel performans ve bu ana } \\
\text { kriterlerin alt kriterleri }\end{array}$ & $\begin{array}{l}\text { Kalite faktörü en önemli faktördür. Bu faktörü Uzun } \\
\text { süreli ilişki ve firma imajı faktörleri takip etmektedir. } \\
\text { en uygun 3PL firmasının \% } 34 \text { ile C firması olduğu ve } \\
\text { \% } 28 \text { ile A firması ikinci en iyi seçenektir. }\end{array}$ \\
\hline
\end{tabular}

Literatürdeki bazı çalışmalarda kriter ağırlıkları eşit kabul edilirken bazı çalışmalarda kriter ağırlıklarının belirlenmesinde öznel değerlendirmelere dayanan yöntemler kullanılmıştır. Bu çalışmada öznellikten uzak objektif değerlendirmeye imkan tanıyan ENTROPİ yöntemiyle kriter ağırlıkları belirlenip EDAS yöntemiyle ülkelerin lojistik performanslarına göre sıralanarak ülkelerin lojistik performanslarının kıyaslanmasında kullanılabilecek objektif bir model oluşturulması hedeflenmiştir.

\section{Materyal ve Metot}

Bu çalışmada; Dünya Bankası tarafından geliştirilen ve 2 yılda bir yayınlanan Lojistik Performans İndeksinin 2018 yılına ait veriler kullanarak Avrupa Birliği ülkeleri ile Türkiye'nin lojistik performansını kıyaslanmak amaçlanmıştır. Bu amaçla Çok Kriterli Karar Verme (ÇKKV) yöntemlerinden ENTROPİ ve EDAS yöntemlerinden faydalanılmıştır. Analizlerde Dünya Bankası tarafindan yayınlanan Lojistik Performans İndeksinde yer alan gümrükler, altyapı, uluslararası sevkiyatlar, lojistik yetkinlik, zamanlama (dakiklik) ile yük izleme ve takip edilebilirlik göstergeleri kriter olarak kullanılmıştır. Ülkelerin kriterlere ilişsin verileri Dünya Bankası web sitesinden (http://www.worldbank.org) alınmıştır. Araştırmaya dahil olan ülkelerin ülke kodu, LPI'ne göre sırası ve araştırma kriterlerine iliş̧kin veriler Tablo 2'de sunulmuştur. Çalışmada ilk olarak ENTROPİ yöntemi ile kıyaslamada kullanılacak kriterlerin önem dereceleri (ağırlıkları) belirlenmiş ve kriterler önem dereceline göre sıralanmıştır. Daha sonra belirlenen kriter ağırlıklarını kullanılarak EDAS yöntemiyle analizler gerçekleştirilerek Avrupa Birliği ülkeleri ile Türkiye'nin lojistik performanslarına göre sıralamaları yapılmış, elde edilen analiz sonuçları bulgular bölümünde sunulmuştur. Ayrıca Çok Kriterli Karar Verme (ÇKKV) yöntemleriyle belirlenen sıralamalar ile Lojistik Performans İndeksine göre sıralamaların karşılaştırılması yapılmıştır.

$\mathrm{Bu}$ çalışmanın iki kısıtı vardır. Birincisi; araştırmaya dahil edilen ülkelerin sayısı ile ilgilidir. İkinci kısıt ise analizlere dahil edilen zaman dilimiyle ilgili olup. analizler yalnızca 2018 yıllı verilerini kullanarak gerçekleştirilmiştir. Çalışma araştırmada kullanılan ÇKKV yöntemlerinden ENTROPİ ve EDAS yöntemlerini birlikte kullanılarak ülkelerin lojistik faaliyetlerinin performansını kıyaslayarak diğer çalışmalardan ayrılmaktadır. 
Tablo 2. Kullanılan Veri Kümesi

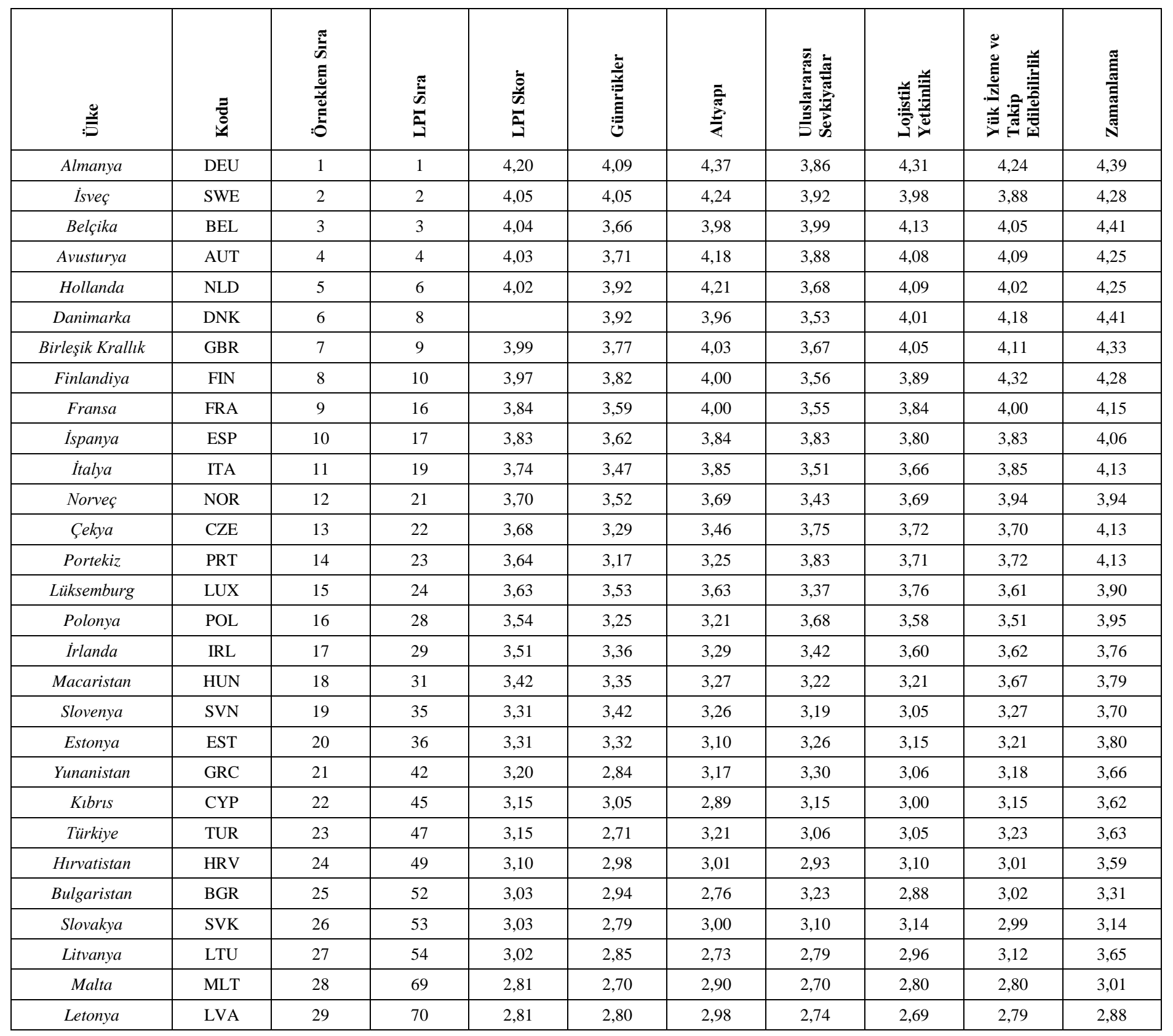

\subsection{Entropi Yöntemi}

Araştırmada kullanılan kriterlerinin önem derecelerinin başka bir ifadeyle ağırlıklarının belirlenmesi problem çözüm aşamasında çok önemli bir aşamayı oluşturmaktadır. Kriterlerin önem derecelerinin belirlenmesinde nesnel ya da öznel çok sayıda yaklaşım bulunmaktadır (Işık, 2019:47). Literatürdeki çalışmalarda sıklıkla kullanılan kriterlerin eşit olarak ağırlıklandırması veya uzmanlar tarafından ağırlıklandırılması, karar verenlerin görüşlerini temel alan sübjektif ağırlıklandırma yöntemleridir. Buna karşın Entropi yöntemi karar vericinin görüşlerine bağlı olmayan objektif bir yöntemdir. Literatürdeki çalışmalarda gerçekleştirilen analizlerin güvenirliğini ve nesnelliğini artırmak amacıyla, kriterlerin ağırlıklandırılması yapılırken Entropi yöntemi tercih edilmektedir (Wu vd., 2011:5163; Yıldırım vd., 2018:137-138). Özellikle sosyal bilimlerde Entropi ağırlıklandırma yöntemi kriter ağırlıklarının tespit edilmesinde sıklıkla kullanılmaktadır (Kenger ve Organ, 2017:155). Entropi Yöntemi 5 aşamadan oluşmaktadır uygulama aşamaları aşağıda verilmiştir (Işık, 2019:47; Zhang vd., 2011:444; Li vd., 2011:2087; Karami, 2014:523-524; Wang, 2009:8982).

Aşama 1. Entropi yönteminin ilk aşamasında eşitlik (1) yardımıyla oluşturulan karar matrisi oluşturulur. Karar matrisi n kriterden $\mathrm{m}$ alternatiften oluşan mxn tipinde bir matristir. Buradaki $\mathrm{a}_{\mathrm{ij}}$; terimleri i. alternatif bakımından $\mathrm{j}$. kriterin değerini belirtir. Bu durumda A karar matrisi aşağıdaki gibidir. 


$$
A_{i j}=\left[\begin{array}{cccc}
a_{11} & a_{12} & \ldots & a_{1 n} \\
a_{21} & a_{22} & \ldots & a_{2 n} \\
\cdot & & & \cdot \\
\cdot & & & \cdot \\
\cdot & & & \cdot \\
a_{m 1} & a_{m 2} & \ldots & a_{m n}
\end{array}\right]
$$

Aşama 2. Entropi yönteminin bu adımında karar matrisi ortak bir birime dönüştürülmek amacıyla normalize edilir. Bu adımda kriterler fayda ve maliyet fonksiyonları ayırt etmeksizin eşitlik (2) yardımıyla normalize edilir. Normalizasyon işlemi sonucunda $\mathrm{R}\left[\mathrm{r}_{\mathrm{ij}}\right]_{\text {mxn }}$ matrisi oluşturulur.

$$
r_{i j=\frac{a_{i j}}{\sum_{i=1}^{m} a_{i j}}}, \quad(\mathrm{i}=1,2,3, \ldots \mathrm{m}, \quad \mathrm{j}=1,2,3, \ldots \ldots, \mathrm{n})
$$

Aşama 3. Kriterlere ilişkin Entropi değerlerinin (e j) hesaplanmasıdır. Bu notasyonda, $e_{j}$. Kriterinin entropi değerini göstermektedir ve $0 \leq \mathrm{e}_{\mathrm{j}} \leq 1$ arasında yer almaktadır.

$$
e_{j}=-k \sum_{j=1}^{n} r_{i j} \ln \left(r_{i j}\right), \quad(i=1,2,3, \ldots, m \text { ve } j=1,2,3, \ldots ., n)
$$

Aşama 4. Bilginin farklılaşma derecesinin (dj) tespit edilmesidir. Bu adımda hesaplanan $\mathrm{d}_{\mathrm{j}}$ değerlerinin yüksek olması kriterlere ilişkin alternatif değerleri arasında karşıtlığın yoğunluğunu başka bir deyişle farklılığın fazla olduğunu göstermektedir.

$$
\mathrm{d}_{\mathrm{j}}=1-\mathrm{e}_{\mathrm{j}} \quad(\mathrm{i}=1,2,3, \ldots, \mathrm{m} \text { ve } \mathrm{J}, \quad \mathrm{i}=1,2,3, \ldots, \mathrm{n})
$$
olur.

Aşama 5. Kriterlere ait Entropi ağırlıklarının $\left(\mathrm{w}_{\mathrm{j}}\right)$ belirlenmesidir. Bu durumda $w_{1}+w_{2}+w_{3}+\cdots . .+w_{j}=1$ eşitliği geçerli

$$
\mathrm{w}_{\mathrm{j}}=\frac{1-\mathrm{e}_{\mathrm{j}}}{\sum_{i=1}^{n} 1-\mathrm{e}_{\mathrm{j}}}
$$

\subsection{EDAS Yöntemi}

EDAS yöntemi ÇKKV yöntemlerinden biri olup Ghorabaee, Zavadskas, Olfat ve Turskis tarafından geliştirilmiştir. EDAS yöntemi, karar verme aşamalarında alternatifler arasından en optimal olanın tespit edilmesinde ortalama çözüm uzaklığına dayalı değerlendirmeleri kullanmaktadır (Akbulut, 2019:254). EDAS yönteminin uygulama aşamaları aşağıdaki gibidir (Zavadskas vd., 2019:257-258; Schitea vd., 2019; Ghorabaee vd., 2015:438-441; Akbulut, 2019:254-257).

Aşama 1. Karar matrisi oluşturulmasıdır. EDAS yönteminin ilk aşamasında diğer ÇKKV yöntemlerinde de olduğu gibi n tane kriter ve $m$ tane alternatifin olduğu karar matrisi nxm boyutlu olarak oluşturulur.

$$
\mathrm{X}=\left[X_{i j}\right]_{n x m}=\left[\begin{array}{cccc}
x_{11} & x_{12} & \ldots & x_{1 m} \\
x_{21} & x_{22} & \ldots & x_{2 m} \\
\vdots & \vdots & \ldots & \vdots \\
\vdots & \vdots & \ldots & \vdots \\
x_{n 1} & x_{n 2} & \ldots & x_{n m}
\end{array}\right]
$$

Aşama 2. Ortalama değerler matrisinin $\left(A V_{j}\right)$ oluşturulmasıdır. EDAS yönteminin ikinci aşamasında Eşitlik (8) kullanarak belirlenen değerlendirme kriterleriyle ilgili ortalama çözüm matrisleri oluşturulur.

$$
A V=\left[A V_{j}\right]_{1 x m}
$$

Aşama 3. Ortalamadan pozitif ve negatif uzaklık matrislerinin oluşturulmasıdır. Bu aşamada kriterleriyle ilgili olarak ortalamadan pozitif uzaklık matrisi (PDA) ve ortalamadan negatif uzaklık matrisi (NDA) oluşturulur. Bu değerlerin hesaplanmasından önce kriterlerin fayda veya maliyet özelliklerine dikkat etmek gerekmektedir. Çünkü hesaplamamlar fayda veya maliyet özelliklerine göre farklılık göstermektedir.

$$
\begin{aligned}
\mathrm{PDA} & =\left[\mathrm{PDA}_{i j}\right]_{n x m} \\
\mathrm{NDA} & =\left[\mathrm{NDA}_{i j}\right]_{n x m}
\end{aligned}
$$

Yukarıdaki eşitliklerde (9) (10) PDA, i. alternatifin j. kriter bakımından ortalama çözüme olan pozitif uzaklığını, NDA ise i. alternatifin j. kriter bakımından ortalama çözüme olan negatif uzaklığını ifade etmektedir. Fayda yönlü kriterler için Eşitlik (11) ve (12) kullanılarak hesaplanır. 


$$
\begin{aligned}
\mathrm{PDA}_{i j} & =\frac{\max \left(0,\left(X_{i j}-A V_{j}\right)\right)}{A V_{j}} \\
\mathrm{NDA}_{i j} & =\frac{\max \left(0,\left(A V_{j}-X_{i j}\right)\right)}{A V_{j}}
\end{aligned}
$$

Maliyet yönlü kriterler için ortalamadan pozitif ve negatif uzaklık değerleri Eşitlik(13) ve (14)'den yararlanılarak hesaplanır.

$$
\begin{aligned}
\mathrm{PDA}_{i j} & =\frac{\max \left(0,\left(A V_{j}-X_{i j}\right)\right)}{A V_{j}} \\
\mathrm{NDA}_{i j} & =\sum_{i=1}^{n} X_{i j} \frac{\max \left(0,\left(X_{i j}-A V_{j}\right)\right)}{A V_{j}}
\end{aligned}
$$

Aşama 4. Ağırlıklı toplam değerlerin hesaplanmasıdır. Bu aşamada ağırlıklı toplam pozitif uzaklıklar $\left(\mathrm{SP}_{i}\right)$ ve ağırlıklı toplam negatif $\left(\mathrm{SN}_{i}\right)$ uzaklıklar Eşitlik (15) ve (16) yardımı ile hesaplanmaktadır. Eşitliklerde yer alan $w_{j}$ her bir değerlendirme kriterinin önem ağırlığını ifade etmektedir.

$$
\begin{aligned}
\mathrm{SP}_{i} & =\sum_{i=1}^{n} w_{j} \mathrm{PDA}_{i j} \\
\mathrm{SN}_{i} & =\sum_{i=1}^{n} w_{j} \mathrm{NDA}_{i j}
\end{aligned}
$$

Aşama 5. Ağırlıklı toplam uzaklıkların normalize edilmesidir. Tüm alternatiflere ait ağırlıklandırılmış ve normalize edilmiş $\mathrm{NSP}_{i}$ ve $\mathrm{NSN}_{i}$ değerleri Eşitlik (17) ve (18) kullanılarak hesaplanmaktadır.

$$
\begin{aligned}
\mathrm{NSP}_{i} & =\frac{\mathrm{SP}_{i}}{\operatorname{mak}\left(\mathrm{SP}_{i}\right)} \\
\mathrm{NSN}_{i} & =1-\frac{S N_{i}}{\operatorname{mak}\left(S N_{i}\right)}
\end{aligned}
$$

Aşama 6. Her bir alternatife ilişkin başarı skorlarının hesaplanmasıdır. Yöntemin son aşamasında bir önceki aşamada hesaplanan $\mathrm{NSP}_{i}$ ve $\mathrm{NSN}_{i}$ değerlerinin ortalaması alınarak her bir alternatif için performans değerlendirmede kullanılacak başarı skorları $\mathrm{AS}_{i}$ Eşitlik (19) kullanılarak elde edilmektedir. Burada en yüksek $\mathrm{AS}_{i}$ değerine sahip alternatif en iyi alternatif olarak değerlendirilir.

$$
\mathrm{AS}_{i}=\frac{1}{2}\left(\mathrm{NSN}_{i}+\mathrm{NSP}_{i}\right)
$$

Her karar alternatifi için hesaplanan değerlendirme skorları 0 ile 1 arasında değer alacaktır. Hesaplamalar sonucunda en yüksek skora sahip karar alternatifi en iyi alternatif olarak belirlenecektir.

\section{Araştırma Sonuçları ve Tartışma}

Çalışmanın bu bölümünde ülkelerin lojistik performanslarının karşılaştıılmasında kullanılan kriterlerin önem dereceleri (ağırlıkları) seçilen ülkelerin 2018 yılı verileri kullanılarak ENTROPİ yöntemiyle belirlenmiş ve elde edilen bulgular sırasıyla sunulmuştur. Sonrasında Türkiye ile Avrupa Birliğine üye 27 ülkenin lojistik performans seviyelerine göre ENTROPİ yöntemiyle belirlenen kriterler ağırlıkları kullanılarak EDAS yöntemiyle sıralanmış ve elde edilen bulgular sırasıyla sunulmuştur.

\subsection{ENTROPİ Yöntemi BulgularI}

Ülkelerin lojistik performans seviyelerinin karşılaştırılmasında kullanılan kriterlerin önem derecelerinin objektif olarak belirlenmesi için uygulanan ENTROPİ yönteminin uygulama adımlarında aşağıdaki bulgular elde edilmiştir.

Adım 1. Entropi yöntemi karar matrisinin oluşturulması. Entropi yönteminde de tüm çok kriterli karar verme yöntemlerinde olduğu gibi ilk aşamada karar matrisi oluşturulmaktadır. Karar matrisi 29 alternatiften ve 6 kriterden oluşan 29x6 tipinde bir matristir. A karar matrisi Tablo 3’te gibidir.

Tablo 3. ENTROPI Yöntemıne İlişkin Karar Matrisi

\begin{tabular}{|c|c|c|c|c|c|c|}
\hline Ülke Kodu & $\mathbf{K}_{\mathbf{1}}$ & $\mathbf{K}_{\mathbf{2}}$ & $\mathbf{K}_{\mathbf{3}}$ & $\mathbf{K}_{\mathbf{4}}$ & $\mathbf{K}_{\mathbf{5}}$ & $\mathbf{K}_{\mathbf{6}}$ \\
\hline$D E U$ & 4,09 & 4,37 & 3,86 & 4,31 & 4,24 & 4,39 \\
\hline$S W E$ & 4,05 & 4,24 & 3,92 & 3,98 & 3,88 & 4,28 \\
\hline$B E L$ & 3,66 & 3,98 & 3,99 & 4,13 & 4,05 & 4,41 \\
\hline$A U T$ & 3,71 & 4,18 & 3,88 & 4,08 & 4,09 & 4,25 \\
\hline
\end{tabular}


Avrupa Bilim ve Teknoloji Dergisi

\begin{tabular}{|c|c|c|c|c|c|c|}
\hline$N L D$ & 3,92 & 4,21 & 3,68 & 4,09 & 4,02 & 4,25 \\
\hline$D N K$ & 3,92 & 3,96 & 3,53 & 4,01 & 4,18 & 4,41 \\
\hline$G B R$ & 3,77 & 4,03 & 3,67 & 4,05 & 4,11 & 4,33 \\
\hline FIN & 3,82 & 4 & 3,56 & 3,89 & 4,32 & 4,28 \\
\hline$F R A$ & 3,59 & 4 & 3,55 & 3,84 & 4 & 4,15 \\
\hline$E S P$ & 3,62 & 3,84 & 3,83 & 3,8 & 3,83 & 4,06 \\
\hline$I T A$ & 3,47 & 3,85 & 3,51 & 3,66 & 3,85 & 4,13 \\
\hline NOR & 3,52 & 3,69 & 3,43 & 3,69 & 3,94 & 3,94 \\
\hline$C Z E$ & 3,29 & 3,46 & 3,75 & 3,72 & 3,7 & 4,13 \\
\hline$P R T$ & 3,17 & 3,25 & 3,83 & 3,71 & 3,72 & 4,13 \\
\hline$L U X$ & 3,53 & 3,63 & 3,37 & 3,76 & 3,61 & 3,9 \\
\hline$P O L$ & 3,25 & 3,21 & 3,68 & 3,58 & 3,51 & 3,95 \\
\hline$I R L$ & 3,36 & 3,29 & 3,42 & 3,6 & 3,62 & 3,76 \\
\hline HUN & 3,35 & 3,27 & 3,22 & 3,21 & 3,67 & 3,79 \\
\hline$S V N$ & 3,42 & 3,26 & 3,19 & 3,05 & 3,27 & 3,7 \\
\hline EST & 3,32 & 3,1 & 3,26 & 3,15 & 3,21 & 3,8 \\
\hline$G R C$ & 2,84 & 3,17 & 3,3 & 3,06 & 3,18 & 3,66 \\
\hline$C Y P$ & 3,05 & 2,89 & 3,15 & 3 & 3,15 & 3,62 \\
\hline$T U R$ & 2,71 & 3,21 & 3,06 & 3,05 & 3,23 & 3,63 \\
\hline$H R V$ & 2,98 & 3,01 & 2,93 & 3,1 & 3,01 & 3,59 \\
\hline$B G R$ & 2,94 & 2,76 & 3,23 & 2,88 & 3,02 & 3,31 \\
\hline$S V K$ & 2,79 & 3 & 3,1 & 3,14 & 2,99 & 3,14 \\
\hline$L T U$ & 2,85 & 2,73 & 2,79 & 2,96 & 3,12 & 3,65 \\
\hline$M L T$ & 2,7 & 2,9 & 2,7 & 2,8 & 2,8 & 3,01 \\
\hline$L V A$ & 2,8 & 2,98 & 2,74 & 2,69 & 2,79 & 2,88 \\
\hline Sütun Toplamı & 97,49 & 101,47 & 99,13 & 101,99 & 104,11 & 112,53 \\
\hline
\end{tabular}

Adım 2. Normalize edilmiş karar matrisinin elde edilmesi. Bu adımda karar matrisi eşitlik (2) yardımıyla fayda ve maliyet özelliklerine göre normalize edilmiştir. Başka bir deyişle, her bir alternatife ait sütun değeri sütun toplamlarına bölünerek normalize edilmiş elde edilen değerler Tablo 4'te sunulmuştur.

Tablo 4. Entropi Yöntemine Göre Normalize Edilmiş Karar Matrisi

\begin{tabular}{|c|c|c|c|c|c|c|}
\hline Ülke & $\mathbf{K}_{1}$ & $\mathbf{K}_{2}$ & $\mathbf{K}_{\mathbf{3}}$ & $\mathbf{K}_{4}$ & $K_{5}$ & $K_{6}$ \\
\hline$D E U$ & 0,04 & 0,04 & 0,04 & 0,04 & 0,04 & 0,04 \\
\hline SWE & 0,04 & 0,04 & 0,04 & 0,04 & 0,04 & 0,04 \\
\hline$B E L$ & 0,04 & 0,04 & 0,04 & 0,04 & 0,04 & 0,04 \\
\hline$A U T$ & 0,04 & 0,04 & 0,04 & 0,04 & 0,04 & 0,04 \\
\hline$N L D$ & 0,04 & 0,04 & 0,04 & 0,04 & 0,04 & 0,04 \\
\hline$D N K$ & 0,04 & 0,04 & 0,04 & 0,04 & 0,04 & 0,04 \\
\hline$G B R$ & 0,04 & 0,04 & 0,04 & 0,04 & 0,04 & 0,04 \\
\hline FIN & 0,04 & 0,04 & 0,04 & 0,04 & 0,04 & 0,04 \\
\hline$F R A$ & 0,04 & 0,04 & 0,04 & 0,04 & 0,04 & 0,04 \\
\hline$E S P$ & 0,04 & 0,04 & 0,04 & 0,04 & 0,04 & 0,04 \\
\hline$I T A$ & 0,04 & 0,04 & 0,04 & 0,04 & 0,04 & 0,04 \\
\hline NOR & 0,04 & 0,04 & 0,03 & 0,04 & 0,04 & 0,04 \\
\hline$C Z E$ & 0,03 & 0,03 & 0,04 & 0,04 & 0,04 & 0,04 \\
\hline$P R T$ & 0,03 & 0,03 & 0,04 & 0,04 & 0,04 & 0,04 \\
\hline$L U X$ & 0,04 & 0,04 & 0,03 & 0,04 & 0,03 & 0,03 \\
\hline$P O L$ & 0,03 & 0,03 & 0,04 & 0,04 & 0,03 & 0,04 \\
\hline$I R L$ & 0,03 & 0,03 & 0,03 & 0,04 & 0,03 & 0,03 \\
\hline
\end{tabular}




\begin{tabular}{|c|c|c|c|c|c|c|}
\hline HUN & 0,03 & 0,03 & 0,03 & 0,03 & 0,04 & 0,03 \\
\hline$S V N$ & 0,04 & 0,03 & 0,03 & 0,03 & 0,03 & 0,03 \\
\hline$E S T$ & 0,03 & 0,03 & 0,03 & 0,03 & 0,03 & 0,03 \\
\hline$G R C$ & 0,03 & 0,03 & 0,03 & 0,03 & 0,03 & 0,03 \\
\hline$C Y P$ & 0,03 & 0,03 & 0,03 & 0,03 & 0,03 & 0,03 \\
\hline TUR & 0,03 & 0,03 & 0,03 & 0,03 & 0,03 & 0,03 \\
\hline$H R V$ & 0,03 & 0,03 & 0,03 & 0,03 & 0,03 & 0,03 \\
\hline$B G R$ & 0,03 & 0,03 & 0,03 & 0,03 & 0,03 & 0,03 \\
\hline$S V K$ & 0,03 & 0,03 & 0,03 & 0,03 & 0,03 & 0,03 \\
\hline$L T U$ & 0,03 & 0,03 & 0,03 & 0,03 & 0,03 & 0,03 \\
\hline$M L T$ & 0,03 & 0,03 & 0,03 & 0,03 & 0,03 & 0,03 \\
\hline$L V A$ & 0,03 & 0,03 & 0,03 & 0,03 & 0,03 & 0,03 \\
\hline
\end{tabular}

Adım 3. Kriterlere ilişkin entropi değerlerinin hesaplanması. Bu aşamada Tablo 5 'teki normalize karar matrisinden yararlanılarak tüm kriterlerin entropi değeri belirlenmiştir. Entropi değerlerinin belirlenmesinde Tablo 4'teki normalize karar matrisindeki her bir değer ile bu değerin logaritma değeri çarpılmıştır. Daha sonra Eşitlik (3) kullanarak sütun toplamı alınmış tüm kriterlerin entropi değerleri ( $\mathrm{e}_{\mathrm{j}}$ ) hesaplanmıştır. Elde edilen değerler Tablo 5 'te sunulmuştur.

Tablo 5. Kriterlere İlişkin Entropi Değerlerinin Hesaplanması

\begin{tabular}{|c|c|c|c|c|c|c|}
\hline Ülke & $\mathbf{K}_{1}$ & $\mathbf{K}_{2}$ & $\mathbf{K}_{3}$ & $\mathbf{K}_{4}$ & $\mathbf{K}_{5}$ & $\mathbf{K}_{6}$ \\
\hline$D E U$ & $-0,133$ & $-0,135$ & $-0,126$ & $-0,134$ & $-0,130$ & $-0,127$ \\
\hline$S W E$ & $-0,132$ & $-0,133$ & $-0,128$ & $-0,127$ & $-0,123$ & $-0,124$ \\
\hline$B E L$ & $-0,123$ & $-0,127$ & $-0,129$ & $-0,130$ & $-0,126$ & $-0,127$ \\
\hline$A U T$ & $-0,124$ & $-0,131$ & $-0,127$ & $-0,129$ & $-0,127$ & $-0,124$ \\
\hline$N L D$ & $-0,129$ & $-0,132$ & $-0,122$ & $-0,129$ & $-0,126$ & $-0,124$ \\
\hline$D N K$ & $-0,129$ & $-0,127$ & $-0,119$ & $-0,127$ & $-0,129$ & $-0,127$ \\
\hline$G B R$ & $-0,126$ & $-0,128$ & $-0,122$ & $-0,128$ & $-0,128$ & $-0,125$ \\
\hline FIN & $-0,127$ & $-0,127$ & $-0,119$ & $-0,125$ & $-0,132$ & $-0,124$ \\
\hline$F R A$ & $-0,122$ & $-0,127$ & $-0,119$ & $-0,123$ & $-0,125$ & $-0,122$ \\
\hline$E S P$ & $-0,122$ & $-0,124$ & $-0,126$ & $-0,123$ & $-0,121$ & $-0,120$ \\
\hline ITA & $-0,119$ & $-0,124$ & $-0,118$ & $-0,119$ & $-0,122$ & $-0,121$ \\
\hline$N O R$ & $-0,120$ & $-0,121$ & $-0,116$ & $-0,120$ & $-0,124$ & $-0,117$ \\
\hline$C Z E$ & $-0,114$ & $-0,115$ & $-0,124$ & $-0,121$ & $-0,119$ & $-0,121$ \\
\hline$P R T$ & $-0,111$ & $-0,110$ & $-0,126$ & $-0,121$ & $-0,119$ & $-0,121$ \\
\hline$L U X$ & $-0,120$ & $-0,119$ & $-0,115$ & $-0,122$ & $-0,117$ & $-0,117$ \\
\hline$P O L$ & $-0,113$ & $-0,109$ & $-0,122$ & $-0,118$ & $-0,114$ & $-0,118$ \\
\hline$I R L$ & $-0,116$ & $-0,111$ & $-0,116$ & $-0,118$ & $-0,117$ & $-0,114$ \\
\hline$H U N$ & $-0,116$ & $-0,111$ & $-0,111$ & $-0,109$ & $-0,118$ & $-0,114$ \\
\hline$S V N$ & $-0,118$ & $-0,110$ & $-0,111$ & $-0,105$ & $-0,109$ & $-0,112$ \\
\hline$E S T$ & $-0,115$ & $-0,107$ & $-0,112$ & $-0,107$ & $-0,107$ & $-0,114$ \\
\hline$G R C$ & $-0,103$ & $-0,108$ & $-0,113$ & $-0,105$ & $-0,107$ & $-0,111$ \\
\hline$C Y P$ & $-0,108$ & $-0,101$ & $-0,110$ & $-0,104$ & $-0,106$ & $-0,111$ \\
\hline TUR & $-0,100$ & $-0,109$ & $-0,107$ & $-0,105$ & $-0,108$ & $-0,111$ \\
\hline$H R V$ & $-0,107$ & $-0,104$ & $-0,104$ & $-0,106$ & $-0,102$ & $-0,110$ \\
\hline$B G R$ & $-0,106$ & $-0,098$ & $-0,112$ & $-0,101$ & $-0,103$ & $-0,104$ \\
\hline$S V K$ & $-0,102$ & $-0,104$ & $-0,108$ & $-0,107$ & $-0,102$ & $-0,100$ \\
\hline$L T U$ & $-0,103$ & $-0,097$ & $-0,100$ & $-0,103$ & $-0,105$ & $-0,111$ \\
\hline$M L T$ & $-0,099$ & $-0,102$ & $-0,098$ & $-0,099$ & $-0,097$ & $-0,097$ \\
\hline$L V A$ & $-0,102$ & $-0,104$ & $-0,099$ & $-0,096$ & $-0,097$ & $-0,094$ \\
\hline $\boldsymbol{e}_{j}$ & 0,998 & 0,997 & 0,998 & 0,997 & 0,998 & 0,998 \\
\hline
\end{tabular}




\begin{tabular}{|c|l|l|l|l|l|l|}
$\left(\boldsymbol{1}-\boldsymbol{e}_{\boldsymbol{j}}\right)$ & 0,002 & 0,003 & 0,002 & 0,003 & 0,002 & 0,002 \\
\hline $\boldsymbol{w}_{\boldsymbol{j}}$ & 0,164 & 0,216 & 0,123 & 0,193 & 0,177 & 0,127 \\
\hline
\end{tabular}

Adım 4. Bilginin farklılaşma derecesinin hesaplanması. Bir önceki adımdan bulunana her bir entropi $\left(\mathrm{e}_{\mathrm{j}}\right)$ değeri 1 sayısından çıkarılmış ve eşitlik (4) yardımıyla “1 - e j” değerleri hesaplanmıştır. Elde edilen değerler Tablo 6'da sunulmuştur.

Adım 5. Kriter ağırlıklarının hesaplanması. Entropi yönteminde son adım kriter ağırlıklarının belirlenmesidir. Bu adımda her bir kriterin ağırlıkları eşitlik (5) yardımıyla elde edilmiştir. Başka bir ifadeyle 1- ej değerleri 1- ej değerlerinin satır toplamına bölünmüş ve her bir kriterin ağırlıkları hesaplanmıştır. Elde edilen değerler Tablo 6'da sunulmuştur.

Kriter ağırlıkları (önem dereceleri) (5) numaralı formül kullanılarak hesaplanmış ve Tablo 6'da gösterilmiştir. Kriterler önem derecelerine göre $\mathrm{K}_{1}$ (gümrükler), $\mathrm{K}_{2}$ (altyap1), $\mathrm{K}_{4}$ (lojistik yetkinlik), $\mathrm{K}_{5}$ (yük izleme ve takip edilebilirlik), $\mathrm{K}_{6}$ (zamanlama) ve $\mathrm{K}_{3}$ (uluslararası sevkiyatlar) biçiminde sıralanmaktadır.

Tablo 6. Kriter Ă̆ırlıkları (Önem Dereceleri)

\begin{tabular}{|c|c|c|c|c|c|c|}
\hline & $\mathbf{K}_{\mathbf{1}}$ & $\mathbf{K}_{\mathbf{2}}$ & $\mathbf{K}_{\mathbf{3}}$ & $\mathbf{K}_{\mathbf{4}}$ & $\mathbf{K}_{\mathbf{5}}$ & $\mathbf{K}_{\mathbf{6}}$ \\
\hline $\boldsymbol{e j}$ & 0,998 & 0,997 & 0,998 & 0,997 & 0,998 & 0,998 \\
\hline$(\mathbf{1}-\boldsymbol{e j})$ & 0,002 & 0,003 & 0,002 & 0,003 & 0,002 & 0,002 \\
\hline$\underline{w} \boldsymbol{j}$ & 0,164 & 0,216 & 0,123 & 0,193 & 0,177 & 0,127 \\
\hline
\end{tabular}

\subsection{EDAS Yöntemi Bulguları}

Türkiye ile Avrupa Birliği ülkelerinin (Almanya, İsveç, Belçika, Avusturya, Hollanda, Danimarka, Birleşik Krallık, Finlandiya, Fransa, ispanya, İtalya, Norveç, Çekya, Portekiz, Lüksemburg, Polonya, İrlanda, Macaristan, Slovenya, Estonya, Yunanistan, Kıbrıs, Hırvatistan, Bulgaristan, Slovak cumhuriyeti, Litvanya, Malta ve Letonya) lojistik performanslarının karşılaştırıldığı EDAS yöntemi uygulama adımlarında aşağıdaki bulgular elde edilmiştir.

Aşama 1. Karar matrisi oluşturulması. EDAS yönteminin ilk aşamasında diğer ÇKKV yöntemlerinde de olduğu gibi 6 tane kriter ve 28 tane alternatiften oluşan karar matrisi $28 x 6$ boyutlu olarak oluşturulmuştur. Tüm kriterler alternatifler ve kriter ağılıklarının içeren birleştirilmiş karar matrisi Tablo 7'de gösterilmiştir.

Aşama 2. Ortalama değerler matrisinin $\left(A V_{j}\right)$ oluşturulması. EDAS yönteminin ikinci aşamasında Eşitlik (8) kullanarak belirlenen değerlendirme kriterleriyle ilgili ortalama çözüm matrisleri oluşturulmuştur. Elde edilen değerler karar matrisi Tablo 7'de gösterilmiştir.

Tablo 7. Birleştirilmiş Karar Matrisi

\begin{tabular}{|c|c|c|c|c|c|c|}
\hline & $K_{1}$ & $\mathbf{K}_{2}$ & $\mathbf{K}_{3}$ & $\mathbf{K}_{4}$ & $\mathbf{K}_{5}$ & $K_{6}$ \\
\hline $\begin{array}{l}\text { Kriterlerin } \\
\text { ĂğIrlıkları }\end{array}$ & 0,143 & 0,188 & $\mathbf{0 , 1 0 7}$ & 0,168 & 0,154 & $\mathbf{0 , 1 1 0}$ \\
\hline & Fayda & Fayda & Fayda & Fayda & Fayda & Fayda \\
\hline Ülke\Kriter & $\mathbf{K}_{1}$ & $\mathbf{K}_{2}$ & $\mathbf{K}_{3}$ & $\mathbf{K}_{4}$ & $\mathbf{K}_{\mathbf{5}}$ & $\mathbf{K}_{6}$ \\
\hline$D E U$ & 4,09 & 4,37 & 3,86 & 4,31 & 4,24 & 4,39 \\
\hline$S W E$ & 4,05 & 4,24 & 3,92 & 3,98 & 3,88 & 4,28 \\
\hline$B E L$ & 3,66 & 3,98 & 3,99 & 4,13 & 4,05 & 4,41 \\
\hline$A U T$ & 3,71 & 4,18 & 3,88 & 4,08 & 4,09 & 4,25 \\
\hline$N L D$ & 3,92 & 4,21 & 3,68 & 4,09 & 4,02 & 4,25 \\
\hline$D N K$ & 3,92 & 3,96 & 3,53 & 4,01 & 4,18 & 4,41 \\
\hline$G B R$ & 3,77 & 4,03 & 3,67 & 4,05 & 4,11 & 4,33 \\
\hline FIN & 3,82 & 4 & 3,56 & 3,89 & 4,32 & 4,28 \\
\hline$F R A$ & 3,59 & 4 & 3,55 & 3,84 & 4 & 4,15 \\
\hline$E S P$ & 3,62 & 3,84 & 3,83 & 3,8 & 3,83 & 4,06 \\
\hline$I T A$ & 3,47 & 3,85 & 3,51 & 3,66 & 3,85 & 4,13 \\
\hline$N O R$ & 3,52 & 3,69 & 3,43 & 3,69 & 3,94 & 3,94 \\
\hline$C Z E$ & 3,29 & 3,46 & 3,75 & 3,72 & 3,7 & 4,13 \\
\hline$P R T$ & 3,17 & 3,25 & 3,83 & 3,71 & 3,72 & 4,13 \\
\hline$L U X$ & 3,53 & 3,63 & 3,37 & 3,76 & 3,61 & 3,9 \\
\hline$P O L$ & 3,25 & 3,21 & 3,68 & 3,58 & 3,51 & 3,95 \\
\hline$I R L$ & 3,36 & 3,29 & 3,42 & 3,6 & 3,62 & 3,76 \\
\hline
\end{tabular}


European Journal of Science and Technology

\begin{tabular}{|c|c|c|c|c|c|c|}
\hline HUN & 3,35 & 3,27 & 3,22 & 3,21 & 3,67 & 3,79 \\
\hline$S V N$ & 3,42 & 3,26 & 3,19 & 3,05 & 3,27 & 3,7 \\
\hline$E S T$ & 3,32 & 3,1 & 3,26 & 3,15 & 3,21 & 3,8 \\
\hline$G R C$ & 2,84 & 3,17 & 3,3 & 3,06 & 3,18 & 3,66 \\
\hline$C Y P$ & 3,05 & 2,89 & 3,15 & 3 & 3,15 & 3,62 \\
\hline TUR & 2,71 & 3,21 & 3,06 & 3,05 & 3,23 & 3,63 \\
\hline$H R V$ & 2,98 & 3,01 & 2,93 & 3,1 & 3,01 & 3,59 \\
\hline$B G R$ & 2,94 & 2,76 & 3,23 & 2,88 & 3,02 & 3,31 \\
\hline$S V K$ & 2,79 & 3 & 3,1 & 3,14 & 2,99 & 3,14 \\
\hline$L T U$ & 2,85 & 2,73 & 2,79 & 2,96 & 3,12 & 3,65 \\
\hline$M L T$ & 2,7 & 2,9 & 2,7 & 2,8 & 2,8 & 3,01 \\
\hline$L V A$ & 2,8 & 2,98 & 2,74 & 2,69 & 2,79 & 2,88 \\
\hline$A V_{j}$ & 3,361 & 3,499 & 3,418 & 3,516 & 3,590 & 3,880 \\
\hline
\end{tabular}

Aşama 3. Ortalamadan pozitif ve negatif uzaklık matrislerinin oluşturulması. Bu aşamada kriterleriyle ilgili olarak ortalamadan pozitif uzaklık matrisi (PDA) ve ortalamadan negatif uzaklık matrisi (NDA) oluşturulur. Tüm kriterler fayda özelliği göstermektedir. Bu nedenle Ortalamadan pozitif uzaklık matrisi (PDA) Eşitlik (11) hesaplanmış ve Tablo 8'de gösterilmiştir.

Tablo 8. Ortalamadan Pozitif Uzakllk (Pdij) Değerleri

\begin{tabular}{|c|c|c|c|c|c|c|}
\hline & $K_{1}$ & $\mathbf{K}_{2}$ & $\mathbf{K}_{3}$ & $\mathbf{K}_{4}$ & $\mathbf{K}_{5}$ & $K_{6}$ \\
\hline$D E U$ & 0,217 & 0,249 & 0,129 & 0,226 & 0,181 & 0,131 \\
\hline$S W E$ & 0,205 & 0,212 & 0,147 & 0,132 & 0,081 & 0,103 \\
\hline$A U T$ & 0,104 & 0,195 & 0,135 & 0,160 & 0,139 & 0,095 \\
\hline$N L D$ & 0,166 & 0,203 & 0,077 & 0,163 & 0,120 & 0,095 \\
\hline FIN & 0,136 & 0,143 & 0,041 & 0,106 & 0,203 & 0,103 \\
\hline$F R A$ & 0,068 & 0,143 & 0,039 & 0,092 & 0,114 & 0,069 \\
\hline$E S P$ & 0,077 & 0,097 & 0,120 & 0,080 & 0,067 & 0,046 \\
\hline ITA & 0,032 & 0,100 & 0,027 & 0,041 & 0,072 & 0,064 \\
\hline$L U X$ & 0,050 & 0,037 & 0,000 & 0,069 & 0,006 & 0,005 \\
\hline$P O L$ & 0,000 & 0,000 & 0,077 & 0,018 & 0,000 & 0,018 \\
\hline$I R L$ & 0,000 & 0,000 & 0,001 & 0,024 & 0,008 & 0,000 \\
\hline HUN & 0,000 & 0,000 & 0,000 & 0,000 & 0,022 & 0,000 \\
\hline$S V N$ & 0,017 & 0,000 & 0,000 & 0,000 & 0,000 & 0,000 \\
\hline$E S T$ & 0,000 & 0,000 & 0,000 & 0,000 & 0,000 & 0,000 \\
\hline GRC & 0,000 & 0,000 & 0,000 & 0,000 & 0,000 & 0,000 \\
\hline$C Y P$ & 0,000 & 0,000 & 0,000 & 0,000 & 0,000 & 0,000 \\
\hline TUR & 0,000 & 0,000 & 0,000 & 0,000 & 0,000 & 0,000 \\
\hline
\end{tabular}


Tüm kriterler fayda özelliği göstermektedir. Bu nedenle ortalamadan negatif uzaklık matrisi (NDA) Eşitlik (12) hesaplanmış ve Tablo 9'da gösterilmiştir.

Tablo 9. Ortalamadan Negatif Uzaklık (Ndij) Değerleri

\begin{tabular}{|c|c|c|c|c|c|c|}
\hline & $\mathbf{K}_{1}$ & $\mathbf{K}_{2}$ & $\mathbf{K}_{3}$ & $\mathbf{K}_{4}$ & $\mathbf{K}_{5}$ & $K_{6}$ \\
\hline$D E U$ & 0,000 & 0,000 & 0,000 & 0,000 & 0,000 & 0,000 \\
\hline SWE & 0,000 & 0,000 & 0,000 & 0,000 & 0,000 & 0,000 \\
\hline$B E L$ & 0,000 & 0,000 & 0,000 & 0,000 & 0,000 & 0,000 \\
\hline AUT & 0,000 & 0,000 & 0,000 & 0,000 & 0,000 & 0,000 \\
\hline$N L D$ & 0,000 & 0,000 & 0,000 & 0,000 & 0,000 & 0,000 \\
\hline DNK & 0,000 & 0,000 & 0,000 & 0,000 & 0,000 & 0,000 \\
\hline GBR & 0,000 & 0,000 & 0,000 & 0,000 & 0,000 & 0,000 \\
\hline FIN & 0,000 & 0,000 & 0,000 & 0,000 & 0,000 & 0,000 \\
\hline$F R A$ & 0,000 & 0,000 & 0,000 & 0,000 & 0,000 & 0,000 \\
\hline$E S P$ & 0,000 & 0,000 & 0,000 & 0,000 & 0,000 & 0,000 \\
\hline ITA & 0,000 & 0,000 & 0,000 & 0,000 & 0,000 & 0,000 \\
\hline NOR & 0,000 & 0,000 & 0,000 & 0,000 & 0,000 & 0,000 \\
\hline$C Z E$ & 0,021 & 0,011 & 0,000 & 0,000 & 0,000 & 0,000 \\
\hline$P R T$ & 0,057 & 0,071 & 0,000 & 0,000 & 0,000 & 0,000 \\
\hline LUX & 0,000 & 0,000 & 0,014 & 0,000 & 0,000 & 0,000 \\
\hline$P O L$ & 0,033 & 0,083 & 0,000 & 0,000 & 0,022 & 0,000 \\
\hline$I R L$ & 0,001 & 0,060 & 0,000 & 0,000 & 0,000 & 0,031 \\
\hline HUN & 0,003 & 0,065 & 0,058 & 0,087 & 0,000 & 0,023 \\
\hline$S V N$ & 0,000 & 0,068 & 0,067 & 0,133 & 0,089 & 0,046 \\
\hline$E S T$ & 0,012 & 0,114 & 0,046 & 0,104 & 0,106 & 0,021 \\
\hline GRC & 0,155 & 0,094 & 0,035 & 0,130 & 0,114 & 0,057 \\
\hline$C Y P$ & 0,093 & 0,174 & 0,078 & 0,147 & 0,123 & 0,067 \\
\hline TUR & 0,194 & 0,083 & 0,105 & 0,133 & 0,100 & 0,065 \\
\hline$H R V$ & 0,114 & 0,140 & 0,143 & 0,119 & 0,162 & 0,075 \\
\hline$B G R$ & 0,125 & 0,211 & 0,055 & 0,181 & 0,159 & 0,147 \\
\hline$S V K$ & 0,170 & 0,143 & 0,093 & 0,107 & 0,167 & 0,191 \\
\hline$L T U$ & 0,152 & 0,220 & 0,184 & 0,158 & 0,131 & 0,059 \\
\hline$M L T$ & 0,197 & 0,171 & 0,210 & 0,204 & 0,220 & 0,224 \\
\hline$L V A$ & 0,167 & 0,148 & 0,198 & 0,235 & 0,223 & 0,258 \\
\hline
\end{tabular}

Aşama 4. Ağırlıklı toplam değerlerin hesaplanması. Uygulamanın bir önceki aşamasında ENTROPİ yöntemi kullanılarak belirlenen kriter ağırlıkları ile Tablo 8'deki her bir değer çarpılarak hesaplanan ağırlıklandırılmış ortalamadan Pozitif uzaklıkların matrisi ve Ağırlıklı toplam pozitif uzaklıklar $\left(\mathrm{SP}_{i}\right)$ uzaklıklar Eşitlik (15) yardımı ile hesaplanmıştır. Elde edilen değerler Tablo 10'da gösterilmiştir.

Tablo 10. Ağırlıklandırılmış Ortalamadan Pozitif Uzaklıklar Matrisi

\begin{tabular}{|c|c|c|c|c|c|c|c|}
\hline & $\mathbf{K}_{\mathbf{1}}$ & $\mathbf{K}_{\mathbf{2}}$ & $\mathbf{K}_{\mathbf{3}}$ & $\mathbf{K}_{\mathbf{4}}$ & $\mathbf{K}_{\mathbf{5}}$ & $\mathbf{K}_{\mathbf{6}}$ & $\mathrm{SP}_{\boldsymbol{i}}$ \\
\hline$D E U$ & 0,036 & 0,054 & 0,016 & 0,043 & 0,032 & 0,017 & 0,197 \\
\hline$S W E$ & 0,034 & 0,046 & 0,018 & 0,025 & 0,014 & 0,013 & 0,150 \\
\hline$B E L$ & 0,015 & 0,030 & 0,021 & 0,034 & 0,023 & 0,017 & 0,138 \\
\hline$A U T$ & 0,017 & 0,042 & 0,017 & 0,031 & 0,025 & 0,012 & 0,143 \\
\hline$N L D$ & 0,027 & 0,044 & 0,009 & 0,031 & 0,021 & 0,012 & 0,145 \\
\hline$D N K$ & 0,027 & 0,028 & 0,004 & 0,027 & 0,029 & 0,017 & 0,133 \\
\hline$G B R$ & 0,020 & 0,033 & 0,009 & 0,029 & 0,026 & 0,015 & 0,131 \\
\hline$F I N$ & 0,022 & 0,031 & 0,005 & 0,020 & 0,036 & 0,013 & 0,128 \\
\hline$F R A$ & 0,011 & 0,031 & 0,005 & 0,018 & 0,020 & 0,009 & 0,094 \\
\hline
\end{tabular}


European Journal of Science and Technology

\begin{tabular}{|c|c|c|c|c|c|c|c|}
\hline$E S P$ & 0,013 & 0,021 & 0,015 & 0,016 & 0,012 & 0,006 & 0,082 \\
\hline$I T A$ & 0,005 & 0,022 & 0,003 & 0,008 & 0,013 & 0,008 & 0,059 \\
\hline NOR & 0,008 & 0,012 & 0,000 & 0,009 & 0,017 & 0,002 & 0,049 \\
\hline$C Z E$ & 0,000 & 0,000 & 0,012 & 0,011 & 0,005 & 0,008 & 0,037 \\
\hline$P R T$ & 0,000 & 0,000 & 0,015 & 0,011 & 0,006 & 0,008 & 0,040 \\
\hline$L U X$ & 0,008 & 0,008 & 0,000 & 0,013 & 0,001 & 0,001 & 0,031 \\
\hline$P O L$ & 0,000 & 0,000 & 0,009 & 0,003 & 0,000 & 0,002 & 0,015 \\
\hline$I R L$ & 0,000 & 0,000 & 0,000 & 0,005 & 0,001 & 0,000 & 0,006 \\
\hline$H U N$ & 0,000 & 0,000 & 0,000 & 0,000 & 0,004 & 0,000 & 0,004 \\
\hline$S V N$ & 0,003 & 0,000 & 0,000 & 0,000 & 0,000 & 0,000 & 0,003 \\
\hline$E S T$ & 0,000 & 0,000 & 0,000 & 0,000 & 0,000 & 0,000 & 0,000 \\
\hline$G R C$ & 0,000 & 0,000 & 0,000 & 0,000 & 0,000 & 0,000 & 0,000 \\
\hline$C Y P$ & 0,000 & 0,000 & 0,000 & 0,000 & 0,000 & 0,000 & 0,000 \\
\hline$T U R$ & 0,000 & 0,000 & 0,000 & 0,000 & 0,000 & 0,000 & 0,000 \\
\hline$H R V$ & 0,000 & 0,000 & 0,000 & 0,000 & 0,000 & 0,000 & 0,000 \\
\hline$B G R$ & 0,000 & 0,000 & 0,000 & 0,000 & 0,000 & 0,000 & 0,000 \\
\hline$S V K$ & 0,000 & 0,000 & 0,000 & 0,000 & 0,000 & 0,000 & 0,000 \\
\hline$L T U$ & 0,000 & 0,000 & 0,000 & 0,000 & 0,000 & 0,000 & 0,000 \\
\hline$M L T$ & 0,000 & 0,000 & 0,000 & 0,000 & 0,000 & 0,000 & 0,000 \\
\hline$L V A$ & 0,000 & 0,000 & 0,000 & 0,000 & 0,000 & 0,000 & 0,000 \\
\hline
\end{tabular}

ENTROPİ yöntemi kullanılarak belirlenen kriter ağırlıkları ile Tablo 9'daki her bir değer çarpılarak hesaplanan ağırlıklandırılmış ortalamadan negattif uzaklıkların matrisi ve ağırlıklı toplam pozitif uzaklıklar $\left(\mathrm{SP}_{i}\right)$ uzaklıklar Eşitlik (16) yardımı ile hesaplanmıştır. Elde edilen değerler Tablo 11'de gösterilmiştir.

Tablo 11. Ağırlıklandırılmış Ortalamadan Negatif Uzaklıklar Matrisi

\begin{tabular}{|c|c|c|c|c|c|c|c|}
\hline & $\mathbf{K}_{1}$ & $\mathbf{K}_{2}$ & $\mathbf{K}_{3}$ & $\mathbf{K}_{4}$ & $\mathbf{K}_{5}$ & $K_{6}$ & $\mathrm{SN}_{i}$ \\
\hline$D E U$ & 0,000 & 0,000 & 0,000 & 0,000 & 0,000 & 0,000 & 0,000 \\
\hline$S W E$ & 0,000 & 0,000 & 0,000 & 0,000 & 0,000 & 0,000 & 0,000 \\
\hline$B E L$ & 0,000 & 0,000 & 0,000 & 0,000 & 0,000 & 0,000 & 0,000 \\
\hline$A U T$ & 0,000 & 0,000 & 0,000 & 0,000 & 0,000 & 0,000 & 0,000 \\
\hline$N L D$ & 0,000 & 0,000 & 0,000 & 0,000 & 0,000 & 0,000 & 0,000 \\
\hline$D N K$ & 0,000 & 0,000 & 0,000 & 0,000 & 0,000 & 0,000 & 0,000 \\
\hline$G B R$ & 0,000 & 0,000 & 0,000 & 0,000 & 0,000 & 0,000 & 0,000 \\
\hline FIN & 0,000 & 0,000 & 0,000 & 0,000 & 0,000 & 0,000 & 0,000 \\
\hline$F R A$ & 0,000 & 0,000 & 0,000 & 0,000 & 0,000 & 0,000 & 0,000 \\
\hline$E S P$ & 0,000 & 0,000 & 0,000 & 0,000 & 0,000 & 0,000 & 0,000 \\
\hline$I T A$ & 0,000 & 0,000 & 0,000 & 0,000 & 0,000 & 0,000 & 0,000 \\
\hline NOR & 0,000 & 0,000 & 0,000 & 0,000 & 0,000 & 0,000 & 0,000 \\
\hline$C Z E$ & 0,004 & 0,002 & 0,000 & 0,000 & 0,000 & 0,000 & 0,006 \\
\hline$P R T$ & 0,009 & 0,015 & 0,000 & 0,000 & 0,000 & 0,000 & 0,025 \\
\hline$L U X$ & 0,000 & 0,000 & 0,002 & 0,000 & 0,000 & 0,000 & 0,002 \\
\hline$P O L$ & 0,005 & 0,018 & 0,000 & 0,000 & 0,004 & 0,000 & 0,027 \\
\hline$I R L$ & 0,000 & 0,013 & 0,000 & 0,000 & 0,000 & 0,004 & 0,017 \\
\hline$H U N$ & 0,001 & 0,014 & 0,007 & 0,017 & 0,000 & 0,003 & 0,042 \\
\hline$S V N$ & 0,000 & 0,015 & 0,008 & 0,026 & 0,016 & 0,006 & 0,070 \\
\hline$E S T$ & 0,002 & 0,025 & 0,006 & 0,020 & 0,019 & 0,003 & 0,074 \\
\hline GRC & 0,025 & 0,020 & 0,004 & 0,025 & 0,020 & 0,007 & 0,103 \\
\hline$C Y P$ & 0,015 & 0,038 & 0,010 & 0,028 & 0,022 & 0,009 & 0,121 \\
\hline TUR & 0,032 & 0,018 & 0,013 & 0,026 & 0,018 & 0,008 & 0,114 \\
\hline
\end{tabular}




\begin{tabular}{|l|l|l|l|l|l|l|l|}
$H R V$ & 0,019 & 0,030 & 0,018 & 0,023 & 0,029 & 0,009 & 0,127 \\
\hline$B G R$ & 0,021 & 0,046 & 0,007 & 0,035 & 0,028 & 0,019 & 0,155 \\
\hline$S V K$ & 0,028 & 0,031 & 0,011 & 0,021 & 0,030 & 0,024 \\
\hline$L T U$ & 0,025 & 0,048 & 0,023 & 0,031 & 0,023 & 0,008 & 0,156 \\
\hline$M L T$ & 0,032 & 0,037 & 0,026 & 0,039 & 0,039 & 0,028 & 0,202 \\
\hline$L V A$ & 0,027 & 0,032 & 0,024 & 0,045 & 0,039 & 0,033 & 0,201 \\
\hline
\end{tabular}

Tablo 10'daki her bir ülkeye ait ortalamadan pozitif uzaklıkların ağırlıklı toplamlarına (SP $i)$ Eşitlik (17) yardımı ile normalizasyon $\left(\mathrm{NSP}_{i}\right)$ işlemi yapılmıştır. Elde edilen $\mathrm{NSP}_{i}$ değerleri Tablo 12 'de gösterilmiştir. Tablo 11 'teki her bir ülkeye ait ortalamadan negatif uzaklıkların ağırlıklı toplamlarına $\left(\mathrm{SN}_{i}\right)$ Eşitlik $(18)$ ile normalizasyon $\left(\mathrm{NSN}_{i}\right)$ ) yapılmıştır. Elde edile $\mathrm{NSN}_{i}$ değerleri Tablo 12 'de gösterilmiştir. Her bir alternatif ülkeye ait değerlendirme puanları $\left(\mathrm{AS}_{i}\right)$ Eşitlik (18) yardımıyla hesaplanmıştır. Asi değerleri ile bu değerlerin sıralaması Tablo 12'de gösterilmiştir.

Elde edilen sonuçlara göre sıralama; Almanya, İsveç, Danimarka, Hollanda, Avusturya, Belçika, Birleşik Krallık, Finlandiya, Fransa, İspanya, İtalya, Norveç, Çekya, Lüksemburg, Portekiz, Polonya, İrlanda, Macaristan, Slovenya, Estonya, Yunanistan, Türkiye, Kıbrıs, Hırvatistan, Litvanya, Bulgaristan, Slovakya, Malta ve Letonya biçimindedir. Almanya ve İsveç yine ilk iki sırada yer almaktadır. Türkiye'nin sırası LPI'ye göre örneklemde 23. Sırada yer alırken analiz sonucunda 22 sıraya yükselmiştir. Almanya ve İsveç Örneklemdeki LPI sırasıyla EDAS yöntemine göre yapılan analiz sonucunda yapılan sıralama arasında fark yoktur.

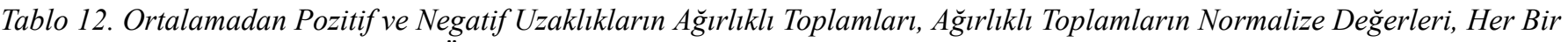
Ülkeye Ait Değerlendirme Puanlart ve Siralamalart

\begin{tabular}{|c|c|c|c|c|c|c|c|c|}
\hline & $\begin{array}{c}\text { Örneklemdeki } \\
\text { LPI Sırası }\end{array}$ & $\mathbf{S P}_{\mathbf{i}}$ & $\mathbf{S N}_{\mathbf{i}}$ & $\mathbf{N S P}_{\mathbf{i}}$ & $\mathbf{N S N}_{\mathbf{i}}$ & $\mathbf{A S} \mathbf{S}_{\mathbf{i}}$ & $\begin{array}{c}\text { EDAS } \\
\text { Sira } \\
\end{array}$ & Değișim \\
\hline Almanya & 1 & 0,084 & 0,000 & 1,000 & 1,000 & 1,000 & 1 & Yoktur \\
\hline Isveç & 2 & 0,067 & 0,000 & 0,797 & 1,000 & 0,898 & 2 & Yoktur \\
\hline Belçika & 3 & 0,059 & 0,000 & 0,701 & 1,000 & 0,850 & 6 & \\
\hline Avusturya & 4 & 0,059 & 0,000 & 0,703 & 1,000 & 0,851 & 5 & \\
\hline Hollanda & 5 & 0,063 & 0,000 & 0,749 & 1,000 & 0,875 & 4 & \\
\hline Danimarka & 6 & 0,063 & 0,000 & 0,753 & 1,000 & 0,877 & 3 & \\
\hline Birleşik Krallık & 7 & 0,058 & 0,000 & 0,693 & 1,000 & 0,847 & 7 & Yoktur \\
\hline Finlandiya & 8 & 0,058 & 0,000 & 0,693 & 1,000 & 0,846 & 8 & Yoktur \\
\hline Fransa & 9 & 0,041 & 0,000 & 0,492 & 1,000 & 0,746 & 9 & Yoktur \\
\hline Íspanya & 10 & 0,032 & 0,000 & 0,387 & 1,000 & 0,693 & 10 & Yoktur \\
\hline Italya & 11 & 0,029 & 0,000 & 0,346 & 1,000 & 0,673 & 11 & Yoktur \\
\hline Norveç & 12 & 0,019 & 0,000 & 0,227 & 1,000 & 0,613 & 12 & Yoktur \\
\hline Çekya & 13 & 0,016 & 0,003 & 0,185 & 0,968 & 0,577 & 13 & Yoktur \\
\hline Portekiz & 14 & 0,016 & 0,012 & 0,195 & 0,870 & 0,532 & 15 & \\
\hline Lüksemburg & 15 & 0,011 & 0,000 & 0,131 & 0,997 & 0,564 & 14 & \\
\hline Polonya & 16 & 0,005 & 0,013 & 0,059 & 0,865 & 0,462 & 16 & Yoktur \\
\hline Irlanda & 17 & 0,001 & 0,011 & 0,013 & 0,882 & 0,447 & 17 & Yoktur \\
\hline Macaristan & 18 & 0,001 & 0,014 & 0,015 & 0,850 & 0,433 & 18 & Yoktur \\
\hline Slovenya & 19 & 0,002 & 0,024 & 0,018 & 0,741 & 0,379 & 19 & Yoktur \\
\hline Estonya & 20 & 0,000 & 0,026 & 0,000 & 0,725 & 0,363 & 20 & Yoktur \\
\hline Yunanistan & 21 & 0,000 & 0,043 & 0,000 & 0,545 & 0,272 & 21 & Yoktur \\
\hline Klbrts & 22 & 0,000 & 0,049 & 0,000 & 0,478 & 0,239 & 23 & \\
\hline Türkiye & 23 & 0,000 & 0,047 & 0,000 & 0,500 & 0,250 & 22 & \\
\hline Hervatistan & 24 & 0,000 & 0,051 & 0,000 & 0,451 & 0,226 & 24 & Yoktur \\
\hline Bulgaristan & 25 & 0,000 & 0,071 & 0,000 & 0,246 & 0,123 & 26 & \\
\hline Slovakya & 26 & 0,000 & 0,074 & 0,000 & 0,210 & 0,105 & 27 & \\
\hline Litvanya & 27 & 0,000 & 0,061 & 0,000 & 0,353 & 0,177 & 25 & \\
\hline Malta & 28 & 0,000 & 0,093 & 0,000 & 0,012 & 0,006 & 28 & Yoktur \\
\hline Letonya & 29 & 0,000 & 0,094 & 0,000 & 0,000 & 0,000 & 29 & Yoktur \\
\hline
\end{tabular}




\section{Sonuç}

Bu çalışmada ülkelerin lojistik faaliyetlerinin performansını kıyaslanabilmesi için dünya bankası tarafından geliştirilen ve 2 yılda bir yayınlanan lojistik performans indeksi (lpı)'nin 2018 yılına ait verilerini kullanarak Avrupa Birliği ülkeleri ile Türkiye'nin lojistik performansı kıyaslanmıştır. Analizlerde çok kriterli karar verme (ÇKKV) yöntemlerinden ENTROPİ ve EDAS yöntemleri kullanılmıştır. Analizlerde Dünya Bankası tarafından yayınlanan Lojistik Performans İndeksinde yer alan gümrükler, altyapı, uluslararası sevkiyatlar, lojistik yetkinlik, zamanlama (dakiklik) ile yük izleme ve takip edilebilirlik göstergeleri kriter olarak kullanılmıştır. Çalışmada ilk olarak ENTROPİ yöntemleri ile kıyaslamada kullanılacak kriterlerin önem dereceleri (ağırlıkları) belirlenmiştir. Daha sonra belirlenen kriter ağırlıklarını kullanılarak EDAS yöntemiyle Avrupa Birliği ülkeleri ile Türkiye'nin lojistik performanslarına göre sıralamaları yapılmıştır. Ayrıca Çok Kriterli Karar Verme (ÇKKV) yöntemleriyle belirlenen sıralamalar ile Lojistik Performans İndeksine göre sıralamaların karşılaştırılması yapılmıştır. Böylece kriter ağırlıkları ve mevcut sıralamayla farklılıkları ortaya konmuştur.

$\mathrm{Bu}$ çalışmada kullanılan kriterlerin önem derecelerinin ENTROPİ yöntemiyle belirlenmesine yönelik analizler sonucunda kriterlerin önem derecelerine göre sıralanması gümrükler, altyapı, lojistik yetkinlik, yük izleme ve takip edilebilirlik, zamanlama ve uluslararası sevkiyatlar biçimindedir. Bu sonuç ülkelerin lojistik performanslarının kıyaslanmasında en önemli kriterin gümrükler kriteri olduğunu göstermektedir. Bu çalışmada ENTROPİ yöntemiyle elde edilen kriter sıralaması Gök Kısa ve Ayçin (2019)'un SWARA yöntemiyle yaptığı kriter sırlamasıyla örtüşmemektedir. Bu farklılığın öznel değerlendirme farklılığından kaynaklanabileceği düşünülmektedir. ENTROPİ yöntemiyle belirlenen kriter ağılıkları kullanılarak EDAS yöntemiyle gerçekleştirilen analizler sonucunda ülkelerin lojistik performans sıralamaları biçiminde Almanya, İsveç, Danimarka, Hollanda, Avusturya, Belçika, Birleşik Krallık, Finlandiya, Fransa, İspanya, İtalya, Norveç, Çekya, Lüksemburg, Portekiz, Polonya, İrlanda, Macaristan, Slovenya, Estonya, Yunanistan, Türkiye, Kıbrıs, Hırvatistan, Litvanya, Bulgaristan, Slovakya, Malta ve Letonya elde edilmiştir. Örneklemdeki LPI Sırası ile EDAS yöntemiyle gerçekleştirilen analizler sonucunda elde edilen sıralamalar karşılaştırıldığında 5 ülke (Hollanda, Danimarka, Lüksemburg, Litvanya ve Türkiye) daha üst sıraya çıkmış,6 ülke (Belçika, Avusturya, Portekiz, Kıbrıs, Bulgaristan ve Slovakya) daha aşağı sıraya düşmüş ve 19 ülke (Almanya, İsveç, Birleşik Krallık, Finlandiya, Fransa, İspanya, İtalya, Norveç, Çekya, Polonya, İrlanda, Macaristan, Slovenya, Estonya, Yunanistan, Hırvatistan, Malta ve Letonya) sırasını korumuştur. Almanya ve İsveç yine ilk iki sırada yer almaktadır. Türkiye'nin sırası LPI'ye göre örneklemde 23. Sırada yer alırken analiz sonucunda 22 sıraya yükselmiştir. Almanya ve İsveç Örneklemdeki LPI sırasıyla EDAS yöntemine göre yapılan analiz sonucunda yapılan sıralama arasında fark yoktur. Bu çalışmada elde edilen ülkelerin lojistik performans sıralamaları Gök Kısa ve Ayçin (2019)'un yaptığı ülkelerin lojistik performans sıralamalarıyla farklılıklar göstermektedir. Bu farklılığın kriter ağırlıklandırılma yönteminin farklılığından kaynaklanabileceği düşünülmektedir.

Türkiye'nin lojistik performans kıyaslamalarında daha üst sıralarda yer alabilmesi için yetkililerin ülkelerin lojistik performans kıyaslamalarında kullanılan en önemli üç kritere (gümrükler, altyapı ve lojistik yetkinlik) gereken önemi vermesi gerekmektedir. Bu bağlamda gümrüklerin iyileştirilmesi, alt yapı olanaklarının ve lojistik yetkinliklerin geliştirilmesi sağlanmalıdır.

Bu çalışmada kullanılan kriterlerin önem dereceleri ENTROPİ yöntemiyle belirlenmiştir. Gelecekte yapılacak çalışmalarda farklı objektif değerlendirmeye imkan sağlayan başka yöntemlerle ve(ya) öznel değerlendirmeye imkan sağlayan yöntemler kullanılarak yapılırsa farklı sonuçlar elde edilebilir. Sıralama yapılırken EDAS yöntemi kullanılmıştır. Gelecekte yapılacak çalışmalarda farklı çok kriterli karar verme (ÇKKV) yöntemleri kullanılırsa farklı sonuçlar elde edilebilir.

\section{Kaynakça}

Aguezzoul, A. ve Pires, S. (2016). 3PL Performance Evaluation and Selection: A MCDM Method. Supply Chain Forum: An International Journal, 17(2), 87-94.

Akbulut, O. Y. (2019). CRITIC ve EDAS Yöntemleri ile İş Bankası'nın 2009-2018 Yılları Arasındaki Performansının Analizi. Ekonomi, Politika \& Finans Araştırmaları Dergisi, 4(2): 249-263.

Akbulut, R. ve Rençber, Ö. F. (2015). BİST’te İmalat Sektöründeki İşletmelerin Finansal Performansları Üzerine Bir Araştırm. Muhasebe ve Finansman Dergisi, Ocak/2015, 117-136

Akman, G. \& Baynal, K. (2014). Logistics Service Provider Selection Through An Integrated Fuzzy Multicriteria Decision Making Approach. Journal of Industrial Engineering, 2014: 1-16.

Asoğlu, İ. \& Eren, T. (2018). AHP, TOPSIS, PROMETHEE Yöntemleri ile Bir İşletme İçin Kargo Şirketi Seçimi. Yalova Sosyal Bilimler Dergisi, 8 (16), 102-122.

Ayrim, Y., Atalay, K. D., \& Can, G. F. (2018). A New Stochastic MCDM Approach Based on COPRAS. International Journal of Information Technology \& Decision Making, 17(03), 857-882.

Aytekin, M. (2018). Lojistikte Yatay İşbirliği. Bursa: Ekin Basın Yayın Dağıtım.

Bağci, H. ve Rençber, Ö. F. (2014). Kamu Bankaları ve Halka Açık Özel Bankaların Promethee Yöntemi İle Kârlılıklarının Analizi, Aksaray Üniversitesi İktisadi ve İdari Bilimler Fakültesi Dergisi, 6(1), 39-47.

Çakır, S. \& Perçin, S. (2013). Çok Kriterli Karar Verme Teknikleriyle Lojistik Firmalarinda Performans Ölçümü. Ege Akademik Bakis, 13(4), 449-459.

Ecer, F. (2018). Third-party Logistics (3PLs) Provider Selection via Fuzzy AHP and EDAS Integrated Model. Technological and Economic Development of Economy, 24(2), 615-634.

Elgün, M. N., \& Aşıkoğlu, N. O. (2016). Lojistik Köy Kuruluş Yeri Seçiminde TOPSIS Yöntemiyle Merkezlerin Değerlendirilmesi. Afyon Kocatepe Üniversitesi İktisadi ve İdari Bilimler Fakültesi Dergisi, 18(1). 0-0. 
Ghorabaee, M. K., Amiri, M., Kazimieras Zavadskas, E. \& Antuchevičienè, J. (2017). Assessment of Third-party Logistics Providers using A CRITIC-WASPAS Approach with Interval Type-2 Fuzzy Sets. Transport, 32(1), 66-78.

Ghorabaee, M. K., Zavadskas, E. K., Olfat, L., \& Turskis, Z. (2015). Multi-criteria inventory classification using a new method of evaluation based on distance from average solution (EDAS). Informatica, 26(3), 435-451.

Gök Kısa, A. \& Ayçin, E. (2019). OECD Ülkelerinin Lojistik Performanslarının SWARA Tabanlı EDAS Yöntemi ile Değerlendirilmesi. Çankırı Karatekin Üniversitesi İktisadi ve İdari Bilimler Fakültesi Dergisi, 9(1), 301-325.

Göleç, A., Gürbüz, F., \& Şenyiğit, E. (2016). Determination of Best Military Cargo Aircraft with Multi-Criteria Decision-Making Techniques. MANAS Journal of Social Studies, 5(5), 87-101.

Görener, A. (2014). Depolama Faaliyetleri İçin Lojistik Servis Sağlayıcı Seçiminde Önemli Değerlendirme Kriterlerinin Belirlenmesi, Uluslararası Yönetim İktisat ve İşletme Dergisi, 10(22), 173-192.

Marti, L., Puertas, R. \& García, L. (2014). The importance of logistics Performance indeks in International Trade. Applied Economics, 46(24), 2982-2992.

Mirzaei, E., Minatour, Y., Bonakdari, H., \& Javadi, A. (2015). Application of Interval-Valued Fuzzy Analytic Hierarchy Process Approach in Selection Cargo Terminals, a Case Study. International Journal of Engineering-Transactions C: Aspects,28(3), 387395.

Oğuz, S, Alkan, G. \& Yılmaz, B. (2019). Seçilmiş Asya Ülkelerinin Lojistik Performanslarının TOPSİS Yöntemi ile Değerlendirilmesi. IBAD Sosyal Bilimler Dergisi, (Özel Sayı), 497-507.

Özbek, A, Demirkol, İ. (2018). Lojistik Sektöründe Faaliyet Gösteren İşletmelerin SWARA VE GİA Yöntemleri İle Analizi. Kırıkkale Üniversitesi Sosyal Bilimler Dergisi, 8 (1), 71-86.

Özbek, A. \& Demirkol, İ. (2018). Lojistik Sektöründe Faaliyet Gösteren İşletmelerin SWARA ve GİA Yöntemleri ile Analizi. Kırıkkale Üniversitesi Sosyal Bilimler Dergisi, 8 (1), 71-86.

Özbek, A. \& Engür. M. (2018). EDAS Yöntemi İle Lojistik Firma Web Sitelerinin Değerlendirilmesi. Selçuk Üniversitesi Sosyal Bilimler Meslek Yüksekokulu Dergisi. 21(2), 417-429.

Özbek, A. \& Eren, T. (2012). Üçüncü Parti Lojistik (3PL) Firmanın Analitik Hiyerarşi Süreciyle (AHS) Belirlenmesi. Uluslararası Mühendislik Araştırma ve Geliştirme Dergisi, 4(2), 46-54.

Özbek, A. (2018). Fortune 500 Listesinde Yer Alan Lojistik Firmaların Değerlendirilmesi. Afyon Kocatepe Üniversitesi İktisadi ve İdari Bilimler Fakültesi Dergisi, 20(1), 13-26.

Özdemir, Ü. \& Güneroğlu, A. (2018). Cargo Type Selection Procedure Using Fuzzy AHP and fuzzy TOPSIS Techniques:'The Case Of Dry Bulk Cargo Ships. International Journal of Shipping and Transport Logistics, 10(3), 259-280.

Percin, S. (2009). Evaluation of Third-party Logistics (3PL) Providers by using A Two-phase AHP and TOPSIS Methodology. Benchmarking: An International Journal, 16(5), 588-604.

Rençber, Ö. F. (2019). Gri İlişkisel Analiz ve VIKOR Yöntemlerinin Karşılaştırılması: İmalat Sektörü Üzerine Örnek Bir Uygulama. Journal of Yaşar University, 14 (Special Issue), 69-81.

Rençber, Ö. F. ve Avcı, T. (2018). BIST'te İşlem Gören Bankaların Sermaye Yeterliliklerine Göre Karşılaştırılması: WASPAS Yöntemi ile Uygulama. Anemon Muş Alparslan Üniversitesi Sosyal Bilimler Dergisi, 6 (ICEESS' 18), 169-175.

Schitea, D., Deveci, M., Iordache, M., Bilgili, K., Akyurt, İ. Z. \& Iordache, I. (2019). Hydrogen Mobility Roll-Up Site Selection Using İntuitionistic Fuzzy Sets Based WASPAS, COPRAS and EDAS, International Journal of Hydrogen Energy, 44(16), 8585-8600.

Sezen Akar, G. \& ÇAKIR, E. (2016). Lojistik Sektöründe Bütünleştirilmiş Bulanık AHP-MOORA Yaklaşımı İle Personel Seçimi, Yönetim ve Ekonomi Araştırmaları Dergisi, 14(2), 185-199.

Şirin, B. \& Emanet, H. (2017). Lojistik Performans Endeksi Kapsamında Orta Asya Türk Cumhuriyetleri’nin Lojistik Performanslarının Analizi Analysis of Logistics Performances of Central Asian Turkish Republics within the Context of Logistics Performance Index. International Conference on Eurasian Economies 2017, 302 -309.

Tüysüz, F., \& Şimşek, B. (2017). A Hesitant Fuzzy Linguistic Term Sets-Based AHP Approach for Analyzing The Performance Evaluation Factors: An Application to Cargo Sector. Complex \& Intelligent Systems, 3(3), 167-175.

Ulutaş, A. \& Karaköy, Ç. (2019). “CRITIC ve ROV Yöntemleri ile Bir Kargo Firmasının 2011-2017 Yılları Sırasındaki Performansının Analiz Edilmesi”, Manas Sosyal Araştırmalar Dergisi, 8(1/1): 229-236.

Ulutaş, A. (2018). ENTROPİ Tabanlı EDAS Yöntemi ile Lojistik Firmalarının PerformansAnalizi. Uluslararası Íktisadi ve İdari Incelemeler Dergisi, (23), 53-66.

Ulutaş, A. (2019). ENTROPİ Tabanlı criti Yöntemi ile Lojistik Firmalarının Performans Analizi. Uluslararası Iktisadi ve İdari Incelemeler Dergisi, (23), 53-66.

Uzun, H. (2013). Kargo Taşımacılık Sektöründe Hizmet Kalitesinin Değerlendirilmesi: AHS ve TOPSIS Yöntemi. Yüksek Lisans Tezi, Gazi Üniversitesi, Sosyal Bilimler Enstitüsü, Ankara.

Yapraklı, T. Ş.ve Ünalan, M. (2017). Küresel Lojistik Performans Endeksi ve Türkiye'nin Son 10 Yıllık Lojistik Performansının Analizi, Atatürk Üniversitesi İktisadi ve İdari Bilimler Dergisi, 31(3) 589-606.

Yayla, A. Y., Öztekin, A., Gümüş, A. T. \& Gunasekaran, A. (2015). A Hybrid Data Analytic Methodology for 3PL Transportation Provider Evaluation using Fuzzy Multi-Criteria Decision Making. International Journal of Production Research, 53(20), 60976113.

Zavadskas, E. K., Stević, Ž., Turskıs, Z. \& Tomašević, M. (2019). EDAS in Minkowski Space (EDAS-M) Method for Evaluating Autonomous Vehicles. Studies in Informatics and Control, 28(3) 255-264. 